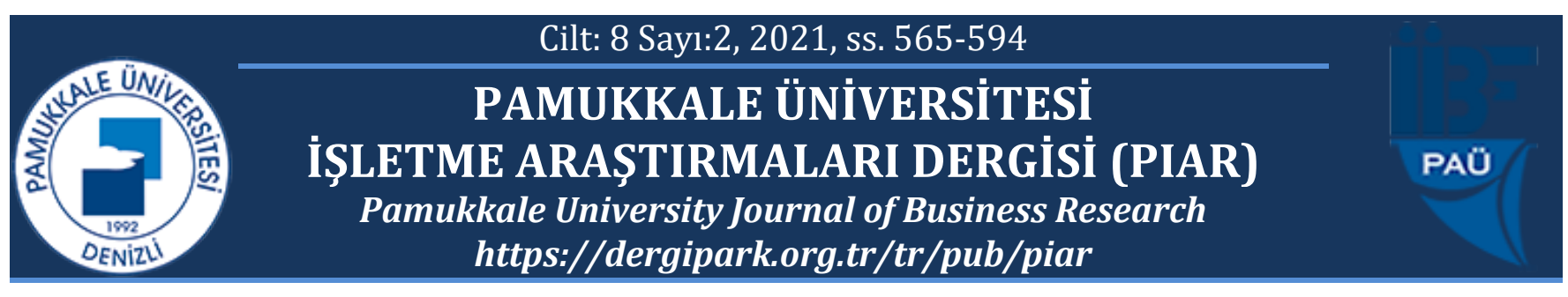

\title{
İşyerinde Yıldırma Davranışları Üzerine Bir Araştırma*
}

\author{
A Research on Mobbing Behaviour in the Workplace
}

Emin BAYINMA ${ }^{1}$

${ }^{1}$ eminbayinma@hotmail.com, https//orcid.org/0000-0003-1810-5305

2 Pamukkale Üniversitesi İ̈BF, sbayrak@pau.edu.tr, https//orcid.org/0000-0002-9118-6327

** Yazışılan Yazar/Corresponding author

Makale Geliş/Received: 01.11.2021

\section{Öz}

İş yaşantısı tarihi süreç içerisinde çalışan ve yönetici tarafiyla kimi zaman avantaj kimi zaman dezavantaj olarak görülen düzenleme ve değişiklikler doğrultusunda çift yönlü bir etkiyle ilerlemiştir. Ancak 1980 sonrası yaşanan sosyo-ekonomik anlamdaki değişimler çalışan tarafin olumsuz yönde derinden etkileyen rekabet ve kârlılık baskılarını getirmiştir. Bu baskılar altında iş hayatında çalışanı usandırmaya yönelik sistematik ve örgütlü birtakım hareket ve yaklaşımlarla iş yaşamı ilişkileri adeta tehdit niteliği kazanmıştır. Yaşanılan bu süreçte çalışanların karşı karşıya kaldığg etik dışı davranışlar karşıllğgı olarak ifade edilen "yıldırma" olgusu ve bu olgusunun yarattığ l olumsuz tutum, davranış ve etkiler, iş hayatında önlemler alınmasını gerektirmektedir. Bu çalışma, günümüzde hem bireysel hem de örgütsel sağllk ve başarının risk faktörlerinden biri olarak karşımıza çıkan yıldırma davranışların bankacılık sektöründe araştırmayı amaçlamaktadır. Bu amaç doğrultusunda 156 kamu ve özel banka çalışanının yaşadığı yıldırma davranışlarının düzeyi ile etkilerini ortaya çıkarmak için anket tekniği ile elde edilen bulgular analiz edilmiştir. Araştırmada ulaşılan bulgular çerçevesinde hipotezler test edilmiş ve örneklemde yıldırma davranışlarının düzeyinin düşük ve etkilerinin yüksek olmadığ $\imath$ tespit edilmiştir. Yıldırma davranışlarının hemen hemen her ülke ve her sektörde artış sağladı̆̆ $ı$ dikkate alınarak farkındalık yaratmak ve konuyla ilgili iyileştirici etkiler için literatürdeki "sıfır yıldırma / zero mobbing" hedefine yönelik öneriler ile çalışmanın alana katkı sağlayacă̆ına inanılmaktadır.

Anahtar kelimeler: Yıldırma, Yildırmanın Etkileri, Banka Çalışanları

JEL kodları: D23, M12, M54

\section{Sabahat BAYRAK KÖK ${ }^{2 * *}$}

Makale Kabul/Accepted: 16.12.2021

\begin{abstract}
Business life has been historically progressing bidirectionally because of the regulations and alterations that are considered as both advantages and disadvantages on behalf of the employee and the executive. However, socio-economic changes in the post80s summoned negative outcomes such as competition and profitability pressure on the employee side. The pressure created systematic and organized behaviors and approaches to tire employees, which causes business life relations to gain a threat-like face. Defined as unethical behaviors that employees encountered during business life, mobbing, and its successors such as negative attitudes, behaviors, and effects requires taking precautions. This study aims to examine mobbing as a risk factor for both personal and organizational wellbeing and success in the Banking sector. 156 participants from public sector banks and private sector banks were surveyed and findings are analyzed to reveal the effects and the level of the previous mobbing experiences. According to the results and the hypothesis tests, the mobbing level and the effects on the sample were found to be low. Considering the rising trend of mobbing behavior in all sectors and countries, it is believed that this study with the suggestions that are in the direction of zero mobbing, will contribute to the literature by raising awareness and providing curative effect.
\end{abstract}

Keywords: Mobbing, Effects of Mobbing, Bank Employee

JEL codes: D23, M12, M54

\footnotetext{
* Bu çalışma, Pamukkale Üniversitesi Sosyal Bilimler Enstitüsü, Yönetim ve Organizasyon (Tezsiz) YL Programı kapsamında Prof. Dr. Sabahat BAYRAK KÖK danışmanlı̆̆ında Emin BAYINMA tarafından hazırlanan "İsyerlerinde Yıldırma Davranışları Üzerine Bir Araştırma" başlıklı bitirme tezinden üretilmiştir.
} 


\section{GİRIŞ}

Küreselleşme olgusunun günümüzde toplumun her alanında gün geçtikçe etkisini arttırarak belirgin hale gelmesi, birtakım amaçların yerine getirilmesi için oluşturulan örgütleri de önemli ölçüde etkisi altına almaktadır. Küreselleşme süreciyle birlikte hem örgütler arası hem de bireyler arası rekabet daha sert ve şiddetli bir hale gelmeye başlamıştır. Rekabetin sertleşmesi ve şiddetini artırması onun yıkıcı ve olumsuz etkilerini örgütlerin daha fazla hissetmesine neden olmakta ve bu durumun bir yansıması olarak örgüt çalışanlarını da negatif yönde etkilemektedir. Oysa çalışanların örgütsel etkinlik ve verimliği yüksek düzeylerde gerçekleştirmesi olumlu ve huzurlu bir ortamda çalışabilmelerinin sağlanmasıyla yakından ilişkilidir. Fakat piyasaların kapitalist eğilimler doğrultusunda hareket etmesi rekabet ve kâr baskısını artırmakta söz konusu baskılar ise çalışanların arzulanan performans düzeylerini yakalamalarında kendilerine yönelmiş olumsuz tutum ve davranışları ortaya çıkarmaktadır (Bayrak Kök, 2006: 434).

Yıldırma kavramı tarihsel olarak incelendiğinde ilk tanımlamaların Lorenz (1963) tarafından hayvanlar üzerinde yapılan çalışmalarla gerçekleştirildiği görülmektedir. Daha sonrasında ise yıldırma kavramının Leymann'ın (1980) örgüt çalışanları üzerinde yaptığı çalışmalarla popüler bir kavram haline gelmeye başladığı anlaşılmaktadır. Konuyla ilgili başlangıç oluşturan bu çalışmaların ardından yıldırma kavramı birçok yazar ve araştırmacı tarafından giderek daha fazla önem kazanmaya başlayan bir olgu haline gelmiştir (Leymann, 1990: 119126; Leymann, 1996: Vartia, 1996: 203-214; 165-184; Einarsen, 1999: 16-27; Zapf,1999: 70-85). Araştırmacılar tarafından yapılan bu çalışmalarda yıldırmanın tanımı birçok yönden farklı şekillerde yorumlanmış olsa da yapılan tanımlar dikkatle incelendiğinde yıldırma olgusunun ortak noktalarının bulunduğu belirlenmiş ve söz konusu tespitler konunun yıldırma olup olmamasının belirlenmesinde hayati değer kazanmıştır.

Yıldırma, geldiğimiz zaman diliminde hemen hemen her örgütte ve kültürde; her düzey ve her pozisyonda ortaya çıkabilen bir olgu olması dolayısıyla bireylerin yıldırmaya maruz kalması muhtemel bir durumdur. Olumsuz ve arzu edilmeyen bir durum olmasına rağmen örgütlerde çalışanların bu davranışlara sık sık maruz kaldıkları görülmektedir. Konuyla ilgili çalışmalara göre gün geçtikçe bu tür olumsuz davranışlar çalışanlar arasında daha fazla yaygınlaşmaktadır. Bu nedenle hem örgüt hem de bireyler açısından ciddi olumsuz etki ve sonuçları olan bir olgu olan yıldırma kavramının detaylı bir şekilde incelenmesi ve onu minimum (hatta sıfır yıldırma) düzeye indirmek amacıyla çok yönlü mücadele ve müdahale edilmesi önemli görülmektedir. Bu çalışmada işyerlerinde sıklıkla cereyan eden yıldırma davranışlarının düzeyinin belirlenmesi ve mağdurlar açısından meydana getirdiği etkilerinin incelenmesi amaçlanmıştır. Çalışanlar arasında ilişki yoğunluğunun ve rekabet şiddetinin yüksek olduğu bilinen bankacılık sektörü bu çalışmanın araştırma alanı olarak belirlenmiştir. Dolayısıyla Denizli ilinde faaliyette bulunan kamu ve özel sektör bankalarının çalışanları araştırmanın evrenini oluşturmaktadır.

\section{KURAMSAL ÇERÇEVE}

Bu başlık altında yıldırma kavramı tanımı, yıldırma davranışları, yıldırma belirtileri ile yıldırma ile mücadele konularında literatürdeki araştırma çerçevesi ele alınmaya çalışılacaktır. 


\subsection{Yıldırmanın Kavramı ve Tanımı}

Geçmişten günümüzde kadar geçen süre içerisinde üzerinde ortaya çıkardı̆̆ 1 olumsuz sonuçlar ve etkiler yeteri kadar düşünülmeyen bir olgu olan yıldırma, bu konuda araştırma ve incelemeler yapılıncaya kadar iş dünyasında doğal bir durum olarak görülmüştür. Ancak son yıllarda dünya genelinde yaygın bir şekilde görülmeye başlanan yıldırma, örgütsel psikoloji alanında başta çalışanlar olmak üzere giderek ilgi gören bir kavram olarak araştırılmaya başlanmıştır (Bayrak Kök vd., 2014: 44). İlk kez bir etolog olan Konrad Lorenz tarafından ele alınan yıldırma kavramı, bir hayvan grubunun diğerlerine karşı saldırgan ve tehdit edici davranışlarını tanımlamak için kullanılmıştır. İsveçli bilim adamı Heinemann; çocukların ders saatleri arasında birbirlerine karşı neler yapabilecekleri ve küçük bir öğrenci grubunun tek bir çocuğa yönelik yıkıcı davranışlarını tanımlamak amacıyla Lorenz'den ödünç almış (Leymann, 1996: 167) ve sonrasında ise Leymann başta olmak üzere pek çok bilim insanı tarafından tanımı yapılmaya başlanmıştır.

Yıldırma kavramı genel olarak; iş arkadaşları, üstler, astlar ve hatta müşteriler tarafından sistematik olarak "yıldırma" davranışları sergilenmesi yoluyla bir çalışanın taciz edildiği durumları ifade eder. Sözcüğün anlam araştırılması yapıldığında literatürde birbirinden farklı terim ve kavramlar aracılığıyla konunun sıkça ele alındığı görülmektedir (Einarsen, 2000: 381). Bu anlamda yıldırma kavramının karşılığı olarak literatürde "psikolojik ve duygusal taciz", "psikolojik şiddet", "işyerinde eziyet", "işyeri terörü" ve "psikolojik yıldırma", "bezdiri” kavramlarının kullanıldığı görülmektedir (Kızıldağ, 2019: 23; Palaz vd., 2008: 43). Yıldırmanın Anglo Sakson kültürde daha fazla "mobbing" kavramıla ifade edildiği söylenebilir. Mobbing, kökeni itibariyle Latincedeki "mobile vulgus" sözcüklerinden türetilmiştir. Bu çerçevesiyle kavram, hareket halinde olan insanlar, şiddet eğilimi olan kalabalık ve topluluk halinde saldırma anlamlarını taşımaktadır. Latincede "mob" kavramı "çete" anlamina gelmektedir. İngilizcede ise "topluluk halinde saldırma", "rahatsızlık verme" şeklinde ifade edilmektedir (Çögenli ve Asunakutlu, 2016: 18; Eser, 2009: 1).

Yıldırma davranışlarının son yıllarda dünya genelinde yaygın bir şekilde görülmeye başlanması nedeniyle başta örgütsel psikoloji alanında olmak üzere konuya yönelik ilgi giderek artmıştır (Bayrak Kök vd., 2014: 44). Yapılan çalışmalarda ister açık ister gizli bir şekilde yapılsın kültürel olarak aykırı bulunan ve belirlenmesi güç olan saldırganca davranışlar yıldırma olarak ifade edilmiştir (Wornham, 2003: 29). Bu açıdan yıldırma konusundaki çalışmalarıyla tanınan Einarsen (1999: 18) yıldırmayı, düşmanca ve/veya yıldırmaya maruz kalan tarafından düşmanca algılanması amaçlanan ve sürekli olarak uygulanan saldırgan davranışlar bütünü olarak tanımlamaktadır. Rayner'e göre (1997: 199) ise yıldırma davranışlarının teşhisi için yıldırma davranışlarının görülme sıklığının belirlenmesi oldukça önemlidir.

Teorik olarak işyerinde aşırı bir sosyal stres kaynağı olan yıldırma, örgütlerde görev yapan bireyleri taciz etmenin en ağır biçimini temsil eder. Böyle olmakla birlikte her anlaşmazlık ve olumsuzluk durumu yıldırma değildir. Bir eylemin yıldırma olarak nitelendirilebilmesi için haftada en az iki kere olmak üzere en az altı ay boyunca tekrarlanması gerekir (Zapf vd., 1996: 215-217). Yapılan tanımlarda "zaman" kavramının ayrıcı özelliğine önem verilerek her davranışın yıldırma olarak kabul görmemesi gerektiğine dikkat çekilmiştir. Genel çerçevesiyle yıldırma, aynı kişiye yönelik sık sık (istatistiksel olarak haftada en az bir kez) ve 
uzun bir süre boyunca (istatistiksel olarak en az altı ay) yapılan, mağdurun kendisini savunmakta zorlandığı aşağılayıcı, korkutucu veya düşmanca davranışları ifade etmekte ve kişileri çaresiz ve savunmasız bir pozisyona iten düşmanca ve etik olmayan davranışlar olarak kabul görmektedir (Leymann ve Gustafsson, 1996: 252). Bu noktada bir kereliğine ortaya çıkan davranışlardan farklı olarak yıldırma ile ilgili tanımlardaki ortak noktalar aşağıdaki şekilde belirtilmektedir (Sperry, 2009: 191; Keim ve McDermott, 2010: 168; Carneroa vd., 2010: 3777):

- Bir ya da daha fazla kişi tarafından bir ya da daha fazla kişinin hedef alınması,

- Mağdurun sağlığına veya ekonomik durumuna zarar vermenin amaçlanması,

- Kasitlı olarak yapılan eylemlerden oluşması,

- Sistematik olarak yapılması,

- Haftada en az iki kez yapılması ve en az altı ay sürmesi,

- Düşmanca ve etik olmayan davranışlardan oluşması şeklinde açıklanabilir.

\subsection{Yıldırma Davranışları}

Günümüzde birçok sektörde önemli bir sorun olarak karşımıza çıkmaya başlayan yıldırmanın (Caponecchia ve Wyatt, 2009: 439) birey, grup ve örgüt dinamiklerini içeren bir süreç olması dolayısıyla detaylı incelenmesi ve çözümünde başarı elde etmek için yıldırma davranışlarının açık olarak tanımlanması ve bilinmesi gerektiğinin önemi belirtilmektedir. Ahlâki ve hukuki değerlerle ilgili bir kavram olarak değerlendirilen kavram kişinin uğradığı en büyük mağduriyeti ifade etmek üzere, fiziksel olarak zulme uğraması, taciz ve benzeri davranışlara maruz kalması şekliyle "psikolojik terör" ve hatta "insan avı" olarak da anılmaktadır (Safina ve Podgornaya, 2014: 187). Bu yönüyle yıldırma davranışlarının çerçevesinin çizilmesi önem arz etmektedir.

Konuyla ilgili araştırmalarda Rayner ve Hoel (1997: 183) birey hakkında dedikodu ve aşırı eleştirilerin yapılması, bireyin sosyal ve fiziksel olarak yok sayılması, kullandığı iletişim araçlarının engellenmesi, aşağılanması ve sözlü olarak taciz edilmesi gibi davranışların yıldırma olarak kabul edilebilen davranışlar olduğunu belirtmiştir. Zapf ve Leymann (1996) ise bir bireyin çalışma ortamında haksız bir şekilde suçlanması, aşağılanması, genel veya duygusal olarak taciz edilmesi yoluyla kötü niyetli bir şekilde zorlanması gibi davranışların yıldırma davranışları olarak tanımlamışlardır. Bazı yazarlara göre de yıldırma özellikle örgütsel bağlamda ortaya çıkan düşmanca eylemler, saldırganlık (sözel, fiziksel, cinsel), mesleki olarak itibarsızlaştırma, hor görme, tecrit vb. olaylardan oluşan bir olguya karşılık gelmektedir (Cornoiu ve Gyorgy, 2013: 708).

Aşağılama, değersizleştirme, itibarı zedeleme, sağlığa zarar vererek rapor kullanmaya zorlama ve çoğu zaman hedef alınan tarafı örgütten uzaklaştırma gibi uzun süren davranışlar birçok işyerinde sıkça görülmektedir (Sperry, 2009: 191). Bu süreçte kaba ve nezaketsiz davranışlar sergilemek yoluyla yıldırmaya maruz kalan tarafın küçümsenmesi, hatalarının ortaya çıkarılması amaçlanırken izleyicilerin ise bu davranışların farkında olmasına rağmen sessiz kalmasıyla yıldırmanın örgütsel kültürün bir parçası haline getirilişi üzerine dikkatler çekilmektedir (Wachs, 2009: 88). Sloan vd., (2010: 88), işyerinde sık sık tekrarlanan yıldırma davranışlarının temelinde hedef alınan bireyin dışlanması, izole 
edilmesi, gerekli veya gereksiz sürekli sorgulanması ve eleştirilmesi, aşağılanması, korkutulması ve küçük düşürülmesi gibi amaçların söz konusu olduğunu ifade etmiştir. Yıldırma davranışında amaç, bireyi yıpratmak ve bireye zarar vermek olduğu için yıldırmayı gerçekleştiren aktörler tarafından birbirinden oldukça farklı yöntemlerin çalışma hayatında uygulandığı görülmektedir. Bu anlamda yukarıdaki davranışlar dışında Ferris (2009), diğer bireyler tarafından iletişimin kesilmesi, bilgi ve desteğin sağlanmaması, kişinin itibarına saldırılması, tehlikeli davranışların tekrarlanması, dışlama, birey ile alay edilmesi, öfkelendirme ve zararlı çalışma ortamına itme gibi davranışları da örnek olarak vermiştir.

Yıldırma davranışları konusunda literatürde en yaygın ve en kapsamlı çalışma Leymann tarafından yapılmıştır. Leymann, yıldırma davranışlarını beş kategoriye ayırarak analitik bir biçimde sınıflandırmıştır. Bu sınıflamaya daha sonra yapılan çalışmalarda "Leymann'ın yıldırma tipolojisi" ismi verilmiştir (Hillard, 2009: 47; Blase ve Blase, 2003: 26-27). Leymann'ın listelediği davranışlar arasında çalışma koşullarının olumsuz yönde değiştirilmesi ya da bireyin performansını olumsuz yönde etkileyecek görevlerin verilmesi, sosyal izolasyon yoluyla dışlanması, aşağılayıcı ve alaycı davranışlara maruz kalması, topluluk içinde küçük düşürülmesi ve eleştirilmesi, asılsız söylentilerin yayılması ve benzeri davranışlar yıldırma olarak değerlendirilmektedir (Acar ve Dündar, 2008: 113).

Tablo 1: Leymann'in Yildırma Tipolojisi

\section{Kendini İfade Etme ve İletişim Kurma Becerisi}

- Yöneticiler, bireyin kendisini ifade etme fırsatını kısıtlıyor.

- Birey sürekli olarak engellenir.

- Çalışma arkadaşları bireyin kendini ifade etme fırsatını kısıtlar.

- Birey azarlanır ve kendisine yüksek sesle bağrilır.

- İşi sürekli olarak eleştirilir.

- Kişisel yaşamı hakkında sürekli eleştiriler yapılır.

- Telefon görüşmelerinde korkutulur.

- Sözlü tehditler alır.

- Yazılı tehditler gönderilir.

- Birey ile iletişim bakışlarla veya jestlerle reddedilir.

- Birey ile iletişim üstü kapalı sözlerle reddedilir.

\section{Sosyal Temaslar Üzerindeki Etkiler}

- Diğerleri artık bireyle konuşmaz.

- Birey kimse ile konuşamaz; başkalarına erişim reddedilir.

- Meslektaşlarından uzakta başka bir odaya yerleştirilir.

- Meslektaşların bireyle konuşması yasaklanır.

- Görmezlikten gelinir. 


\section{Kişisel İtibar Üzerindeki Etkiler}

- İnsanlar birey hakkında arkasından kötü konuşurlar.

- Birey hakkında asılsız söylentiler ortaya atılır.

- Gülünç duruma düşürülür.

- Zihinsel rahatsızlığı varmış gibi davranılır.

- Psikiyatrik bir değerlendirmeye tabi tutulur.

- Yetersizlikleri ile alay edilir.

- İnsanlar, birey ile alay etmek için jestlerini, yürüyüşünü veya sesini taklit eder.

- Siyasi ya da dini inançları ile alay edilir.

- Özel hayatıyla alay edilir.

- Milli kimliği ile alay edilir.

- Birey, itibarını etkileyen işlerde çalışmaya zorlanır.

- Çabaları yanlış ve alçaltıcı bir şekilde değerlendirilir.

- Kararları her zaman sorgulanir.

- Küçük düşürücü isimlerle çağırılır.

- Cinsel temaslara maruz kalır.

\section{Mesleki Durum ve Yaşam Kalitesi Üzerine Etkiler}

- Bireye özel görevler verilmez.

- Denetim otoriteleri görevlerini yerine getirir, böylece yapılacak yeni görevler elde edemez.

- Anlamsız işler verilir.

- Niteliklerinin altında işlerde çalıştırılır.

- Sürekli olarak farklı görevler verilir.

- İtibarını etkileyen görevler verilir.

- İtibarına zarar vermek için niteliklerinin çok ötesinde bir görev verilir.

- Genellikle finansal maliyetlere yol açan hasarlara neden olunur.

- Yöneticiler tarafından işine veya evine zararlar verilir.

\section{Fiziksel Sağlık Üzerindeki Etkiler}

- Birey fiziksel olarak yorucu işler yapmaya zorlanır.

- Fiziksel şiddet tehditleri yapilır.

- Açık şiddet bireyi tehdit etmek için kullanılır.

- Fiziksel taciz uygulanir. 
- $\quad$ Birey cinsel olarak tacize maruz kalır.

Kaynak: Blase ve Blase, 2003: 26-27; Hillard, 2009: 47.

\subsection{Yıldırmanın Belirtileri}

İnsan haklarına ve etiğe uygun olmayan yıldırma, çoğunlukla fiziksel ve psikolojik rahatsızlıkların önemli bir belirtisi olmakta ve kişileri davranışsal ve fiziksel yönde etkileyebilmektedir. Bu durum ise ciddi hastalıklara, mesleki sakatlıklara, gelir kaybına ve hatta intihara bile yol açabilmektedir (Groeblinghoff ve Becker, 1996: 277-278). Bu durumda bazı belirtilerin olması yıldırmanın örgütteki varlığına işaret olarak kabul görmektedir (Çögenli ve Karadaş, 2019: 36). Başka bir deyişle bir örgütte yıldırma davranışları uygulanmaya başladıkça etkileri ve/veya belirtileri de ortaya çıkmaya başlamaktadır. Bu durumlarda özellikle yıldırmaya maruz kalan mağdur üzerinde birtakım belirtiler meydana gelmekte ve bu belirtiler uzun vadede bireyi rahatsız etmektedir. Duyulmaya başlanan güvensizlik hissi, sindirim problemleri ve uykusuzluk bunlar arasında en sık görülen belirtiler olarak sayılabilir (Cornoiu ve Gyorgy, 2013: 710). Yıldırmanın belirtileri farklı şekillerde ortaya çıkabilir ancak bu belirtileri genel olarak; davranışsal ve fiziksel belirtiler olmak üzere iki şekilde gruplandırılabiliriz (Tınaz, 2006a: 16).

\subsubsection{Davranışsal Belirtiler}

İşyerinde meydana gelen birtakım davranışlar, mağdura yönelik yıldırma sürecinin başladığına işaret eden davranışsal belirtilerdir (Şerifoğlu, 2019: 24). Bu davranışlar arasında mağdurun sürekli olarak eleştirilmesi ve küçümsenmesi, diğerlerinin yanına geldiğinde konuşmaların kesilmesi veya konunun değiştirilmesi, bireyin çalışma ortamında rahatsız edilmesi sayılabilir ve bunlar yıldırmanın davranışsal belirtileri olarak kabul edilmektedir. Sayılanlar dışında birey hakkında farklı söylentilerin ortaya atılması, kendisine yeteneklerinin altında görevler verilmesi, sözlü veya yazılı taleplerine karşılık alamaması ve alay konusu edilmesi gibi davranışlar da işyerinde yıldırmanın davranışsal belirtileri arasindadir (Tinaz, 2006a: 16-17).

Genellikle görülen diğer davranışsal belirtiler ise, bireyin konuşmaya başladığında sözünün kesilmesi, işi veya özel yaşantısının eleştirilmesi, sözlü veya yazılı olarak tehditler alması, birey ile iletişim kesilmesi, işyerinde yokmuş gibi davranılması ve onurunu zedeleyici davranışlara maruz kalması gibi durumlar (Polat ve Pakiş, 2012: 212) sayılabilir. Bayram (2010) çalışanın yüzüne karşı bağırılmasını, yüksek sesle azarlanmasını, gülünç duruma düşürülmesini, alay konusu edilmesini yıldırmanın davranışsal belirtileri arasında görmek gerektiğini ifade etmektedir. Yine kişinin fiziksel olarak ağır işler yapmaya zorlanması, yetkilerinde kisitlamalar yapılması, cinsel tacize maruz kalması ve benzeri durumlar da davranışsal belirtiler arasında sıralanmaktadır.

\subsubsection{Fiziksel Belirtiler}

Yıldırma, birtakım fiziksel rahatsızlıkları beraberinde getiren bir süreçtir. Bu rahatsızlıklar, yıldırmanın fiziksel belirtileri olarak görülebilir (Divincova ve Sivakova, 2014: 23). Nitekim yıldırma ile ilgili yapılan çalışmalar, yıldırma mağduru olan çalışanların ciddi fiziksel sorunlar yaşadığını göstermektedir (Ertürk ve Cemaloğlu, 2014: 3670). Dick ve Wagner (2001), yıldırmaya maruz kalan bireylerin yorgun, endişeli ve aşırı bir şekilde stresli 
göründüğünü ve bunun gibi fiziksel belirtilerin çok sık meydana geldiğini ifade etmiştir. Einarsen ve Mikkelsen (2003) ise, bireyin yıldırma mağduru olduğunu gösteren belirtilerinden biri olarak mağdurun kendisini fiziksel olarak diğerlerinden soyutlamasını ve içine kapanmasını örnek vermiştir (İdiğ Çamuroğlu ve Minibas Poussard, 2017: 58).

Yıldırmaya maruz kalan bireylerde uyku sorunları (Hansen vd., 2014: 285) yanı sıra, endişe ve yorgunluk (Raknes vd., 2014: 479), tükenmişlik (Trepanier vd., 2015: 105), genel stres ve zihinsel stres reaksiyonları (Hogh vd., 2011: 107) gibi fiziksel belirtiler de meydana gelmektedir. Ayrıca işyerinde fiziksel şiddet olaylarının görülmesi de örgüt içerisinde yıldırmanın var olduğunu gösteren en önemli belirtilerden biri olarak kabul edilmektedir (Mulder vd., 2017: 16). Bunlara ek olarak bireyin panik atak geçirmesi, sıkıntılı görünmesi, dikkat dağınıklığı yaşaması, titremesi, çok sık terlemesi ve nefes almakta güçlük çekmesi gibi fiziksel belirtiler, bireyin yıldırma mağduru olduğunun en önemli belirtileri arasındadır (Tinaz, 2006a: 18).

\subsection{Yıldırma ile Mücadele}

Gün geçtikçe daha korkutucu boyutlara ulaşan yıldırma davranışlarının sosyal, insani ve ekonomik olarak ağır bedellerinden korunmak için yıldırma ile mücadelede ortak önlemlerin alınması ve etkin mücadele yollarının belirlenmesi zorunluluk haline gelmiştir (Tınaz, 2006b: 14). Ancak yıldırma olgusu birtakım problemleri içinde barındırdığından dolayı yıldırma ile mücadele etmek de aynı şekilde çok zor bir aşamadır (Staub, 2015: 5). Ayrıca yıldırmanın etkisi geniş bir alana yayıldığından mücadele de geniş bir alana yayılması gerekmektedir. Yıldırma ile mücadelenin geniş bir alanda sürdürülebilmesi için sürecin içinde yer alanların kişilik özelliklerine, örgüt ve toplum kültürüne, durumun şiddetine ve bulunduğu aşamaya göre gereken düzenlemeler yapılmalıdır.

Diğer taraftan herkese uygun bir mücadele yönteminin uygulanması pratikte zor olabilir. Dolayısıyla yıldırma ile mücadele sürecinde ortak noktalara göre hareket edilmesi gerekmektedir (Karslığlu Yeni, 2013: 63). Yıldırma ile mücadele edilebilmesi için birçok yazar tarafından farklı yöntemler önerilmiş ve farklı başlıklar altında toplanmıştır. Genel olarak bakıldığında yıldırma ile mücadele bireysel, örgütsel ve hukuksal mücadele olmak üzere üç başlık altında incelenmektedir (Gücenmez, 2007: 81; Mizrahi, 2013: 447).

\subsubsection{Bireysel Mücadele}

Yıldırma sürecinin içindeki bireyler, yıldırmanın önlenmesinde veya durdurulmasında potansiyel olarak ciddi bir rol üstlenebilir (Mulder vd., 2017: 22-23; Leymann, 1996: 176). Bununla birlikte yıldırma ile mücadelede farkındalığın sadece belirli bireylerin sorumluluğuna bırakılmaması ve ayrıca her bireyin bu konuda farkındalık oluşturması en önemli noktalardan biridir. Dolayısıyla her birey bir şeyler yapmalı ve yıldırma ile mücadele etmelidir (Tetik, 2010: 86). Bu noktadan hareketle yıldırma ile mücadelede en büyük görevin bireylere düş̧üğü söylenebilir. Bireyler tarafından alınacak önlemler yıldırma ile mücadelenin etkin bir şekilde yapılmasını sağlayacaktır (Şen, 2017: 141).

Bireylerin yıldırma ile mücadelede birçok yönteme başvurduğu görülmektedir. Bu yöntemlere Rayner (1997: 206) yıldırma aktörleri ile yüzleşme, hiçbir şey yapmama, insan kaynakları yöneticisine veya meslektaşlara danışma ya da işi bırakma davranışlarını örnek vermiştir. Keashly vd., (1994: 344) ise bireylerin faillerden kaçarak veya faille nasıl başa 
çıkacağı hakkında başkalarının fikirlerini alarak yıldırma ile mücadele edebileceğini belirtmiştir. Son olarak Genç ve Erdiş (2015: 2016) yıldırmanın yöneticiler tarafından uygulanmaması halinde, durumun yöneticilere iletilmesi ve bu süreçte birtakım hususlara dikkat etmesi gerektiğini belirtmiştir. Dikkat edilmesi gereken hususlardan biri, yıldırmanın ispatlanabilmesi için yazışma, not, mesaj, e-posta, gibi her türlü bilgi ve belgenin titizlikle korunmasıdır. Diğeri ise sürece şahit olanlarla görüşmelerin yapılması ve son olarak ise hukuki yollara başvurulmasıdır.

\subsection{2. Örgütsel Mücadele}

Yıldırma davranışları işyerinde meydana geldiğinden dolayı örgütsel olarak yıldırma ile mücadele yöntemleri büyük bir öneme sahiptir. İsyerinde yöneticiler tarafından insan kaynakları politikaları oluşturulurken yıldırmanın göz ardı edilmemesi ve ortaya çıkmasını önleyici tedbirlerin alınması gerekir (Özyer ve Orhan, 2012: 516). Ayrıca kamu kurumları ve özel sektör örgütleri, oluşumlarını gerçekleştirirken ya da devam ettirirken yıldırma ile ilgili zihinsel dönüşümü sağlaması ve örgütün tüm üyelerine yönelik eğitim odaklı çalışmalar yapması çözümü kolaylaştıracaktır (Pehlivan, 2015: 77). Bir diğer önemli nokta ise yıldırmanın örgütte önlenmesinde ve mücadele sürecinde yöneticilerin üstlendikleri roldür. Söğütlü (2014: 61), örgütlerin yönetici seçiminde dikkatli olması gerektiğini ve yöneticilerin yıldırma ile mücadelede birtakım özelliklere sahip olması gerektiğini belirtmiştir. Örgütsel mücadelede iletişimin geliştirilmesi, örgüt kültürünün ve örgüt ikliminin oluşturulması gibi faktörler de göz ardı edilmemelidir (Ertuna ve Ertuna, 2015: 134-135).

Yıldırmayla mücadele edebilmek için örgütler, çalışanları için hizmet içi eğitimler planlamalı ve yıldırma ile mücadeleye yönelik beceri eğitimleri vermeli, yıldırma davranışlarının örgüte bildirilmesi için gerekli imkânlar sağlamalı ve yıldırmaya maruz kalan çalışanlarını bu konuda cesaretlendirmelidir (Kehribar vd., 2017: 7). Örgütün kalbinin insan olduğu yaklaşımıyla daha güvenli bir çalışma ortamı sağlanabilmesi için yönetim anlayışının yeniden organize edilmesi de yıldırma ile mücadelede katkı sağlayacaktır (Mercanlığlu, 2010: 42). Ayrıca Şerifoğlu'na (2019: 46) göre yıldırma ile mücadelede örgütsel olarak atılması gereken en temel adımlar aşağıdaki gibidir:

- Örgüt yapılanması dikey olarak değil yatay olarak yapılmalıdır. Gücün merkezileşmesi önlenmeli ve güç tüm örgüte dağıtılmalıdır.

- Tüm örgüt üyeleri tarafından benimsenen bir örgüt kültürü oluşturulmalıdır. Ayrıca örgüte yeni katılan çalışanlar bu konuda bilinçlendirilmelidir.

- Güven duygusu geliştirilmeli, çalışanların problemlerini açık bir şekilde paylaşması sağlanmalı ve nereye başvuracakları hakkında bilgi verilmelidir.

\subsubsection{Hukuksal Mücadele}

Türk Hukuku'nda yıldırma ile ilgili doğrudan hukuki bir düzenlemeye henüz yer verilmemiştir. Bununla birlikte yıldırma ile mücadelenin güçlendirilebilmesi ve yıldırma davranışlarının önlenebilmesi için yasa koyucular tarafından bir an önce etkin bir yaptırımı olan düzenlemelerin yapılarak boşluğun doldurulması gerektiği araştırmacılar tarafından ifade edilmektedir (Koçak ve Yeşilyurt, 2014: 214). Doğrudan bir düzenleme olmasa da yıldırma hukuksal açıdan bir suç ve insan hakkı ihlali olarak kabul edilmektedir (Çimen ve Saç, 2017: 188). Diğer taraftan özellikle başta İsveç, Hollanda, Danimarka, Finlandiya, Fransa 
ve Belçika gibi birçok Avrupa Birliği ülkesinde yıldırma ile ilgili hukuki düzenlemeler söz konusudur (Tunç, 2017: 412). Bu konuda Türkiye'nin de taraf olduğu Uluslararası Çalışma Örgütü (ILO) tarafından yayınlanan düzenlemeler, iç hukukta değerlendirilmektedir. Türk hukukunda ise Türk Borçlar Kanunu ve Türkiye İnsan Hakları ve Eşitlik Kurumu Kanunu'nun dişında doğrudan bir atıf bulunulmamakta ve konu mevzuattaki mevcut hükümlerle yargı kararlarına konu olmaktadır (www.mobbing.org.tr, Erişim Tarihi: 12.10.2021).

Bilge (2016: 1252), yıldırma ile mücadelede yapılması gerekenler olarak ceza hukuku açısından yıldırma uygulayan kişinin "fail" ve hedef alınan kişinin ise "mağdur" ve ceza muhakemesi hukuku açısından izleyicilerin de "tanık" olarak değerlendirilebileceğini tavsiye etmiştir. Ancak hukuki olarak gerekli düzenlemeler olmadığından dolayı yıldırmaya maruz kalan bireylerin hukuksal olarak mücadele verebilmesi için çalıştıkları örgüte şikâyet dilekçesi yazabileceğini veya adli makamlara başvurabileceğini ifade etmiştir. Son olarak Türkiye Büyük Millet Meclisi Kadın Erkek Fırsat Eşitliği Komisyon’u tarafından hazırlanan raporda yıldırma mücadelede bireylerin hukuksal olarak aşağıdaki adımlara başvurulabilecekleri ifade edilmiştir (TBMM, 2011: 78-79):

- Yıldırma uygulanması halinde savcılığa veya personel müdürlügüne durum bildirilmelidir.

- Hukuksal olarak delil oluşturması için ilk fırsatta yıldırma uygulayan kişi rapor edilmeli, tıbbi ve psikolojik yardım alınmalıdır.

- Çalışanlar, işe alınırken yıldırma uygulamayacağına yönelik yemin belgesi imzalamalıdır.

\section{YILDIRMA DAVRANIŞLARININ İNCELENMESINNE YÖNELİK BİR ARAŞTIRMA}

\subsection{Araştırmanın Amacı}

$\mathrm{Bu}$ çalışmada banka çalışanları arasında görülen yıldırma davranışlarına, yıldırmanın düzeyine dikkat çekmek ve böylece yıldırma olgusunun doğru bir şekilde algılanmasını sağlamak amaçlanmıştır. Bu amaç kapsamında Denizli ilinde faaliyet gösteren banka çalışanları üzerinde anket yöntemi kullanılarak yıldırma davranışları araştırılmıştır. Bununla birlikte banka çalışanları arasında görülen hangi davranışların yıldırma olarak algılandığı ve bunun sonucunda meydana gelen belirti ve/veya etkilerin neler olduğu araştırılmıştır. Bu amaç doğrultusunda aşağıdaki sorulara cevap aranmaya çalışılmıştır:

1. Örneğimizde yer alan banka çalışanlarında yıldırma ne düzeydedir?

2. Örneğimizde yer alan yıldırma davranışları hangi boyutta daha önemli görülmektedir?

3. Banka çalışanların algılamış oldukları yıldırma davranışlarının belirtileri nelerdir?

Araştırmanın yöntemi olarak kullanılan anket formu ise üç bölümden oluşmaktadır. Birinci bölümde ankete katılan banka çalışanları hakkında bilgi elde etmek amacıyla 5 adet ifade yer almaktadır. Bu ifadeler, çalışanların cinsiyetine, medeni durumuna, yaşına, eğitim düzeyine, işyerinde elde ettiği tecrübeye ve mevcut görevine yöneliktir. İkinci bölümde ise işyerinde 
maruz kalınan yıldırma davranışları ile ilgili 33 ifade bulunmaktadır. Son olarak üçüncü bölümde ise yıldırmanın etkilerini belirlemek amacıyla 22 ifadeye yer verilmiştir.

\subsection{Araştırmanın Evreni ve Örneklemi}

Yıldırma davranışlarını ve belirtilerini incelemek amacıyla yürüttügüumüz araştırmada evren Denizli ilindeki kamu ve özel sektörde faaliyet gösteren banka çalışanlarından oluşmaktadır. Araştırma örneklemini ise bankalardan alınan veriler doğrultusunda toplam 800 özel banka çalışanı ve 760 kamu bankası çalışanı oluşturmaktadır. Araştırmada örneklem miktarının belirlenebilmesi için \%10 kota örnekleme yöntemi kullanılmıştır. Bu yönteme göre kamu bankalarının ve özel bankaların toplam çalışan sayısının \%10'u örneklem olarak belirlenmiş ve 800 özel banka çalışanının \%10'unun alınmasıyla 80 özel banka çalışanı örnekleme alınmıştır ( $Q_{1}=800 \times 0,10$ formülüne göre $Q_{1}=80$ çalışan). 760 kamu bankası çalışanının da aynı yöntemle \%10'u alındığında 76 kamu bankası çalışanı örnekleme dâhil edilmiştir $\left(\mathrm{Q}_{2}=760 \times 0,10\right.$ formülüne göre ise $\left.\mathrm{Q}_{2}=76\right)$. Bu doğrultuda 156 banka çalışanın 80'i özel bankaları ve 76'sı kamu bankalarını temsil etmiştir.

\subsection{Araştırmanın Yöntemi ve Veri Toplama Araçları}

Yıldırma davranışlarının ve belirtilerinin banka çalışanları arasında incelenebilmesi için sosyal bilimler alanındaki çalışmalarda en sık kullanılan veri toplama aracı olan anket yöntemi kullanılmıştır. Bu doğrultuda banka çalışanlarına iletilen anket formunda demografik özelliklere ilişkin 8 ifadeye, yıldırma davranışlarının incelenebilmesi için 33 ifadeye ve yıldırmanın belirtilerinin incelenebilmesi için 22 ifadeye yer verilmiştir. Araştırmada kullanılan demografik özelliklere ilişkin çalışanlara yöneltilen ifadeler, araştırmacı tarafından araştırma amacı kapsamında Denizli ilindeki kamu bankası ve özel banka çalışanlarına yönelik oluşturulmuştur.

Yıldırma davranışlarının ve belirtilerinin incelenebilmesi için kullanılan anket formu ise literatürde bu konuda yapılan (Leymann, 1996; Zapf vd., 1996; Niedl 1996; Davenport vd., 1999; Fox ve Stallworth, 2003) çalışmalardan uyarlanarak geliştirilen ve iki bölümden oluşan Yousef, Houfey ve Elserogy (2013) anketidir. Anketin birinci bölümünde 33 ifade ve 4 boyuttan oluşan yıldırma davranışlarının belirlenmesine yönelik ifadeler bulunmaktadır. 33 ifadenin 11'i kendini gösterme ve iletişime saldırılar boyutunu, 9'u çalışma kalitesi ve mesleki duruma saldırılar boyutunu, 9'u itibar ve saygınlığa saldırılar boyutunu, 4'ü ise sağlığa doğrudan saldırılar boyutunu temsil etmektedir. Anketin ikinci bölümünde ise 22 ifade ve 3 boyuttan oluşan yıldırmanın belirtilerinin incelendiği ifadeler yer almaktadır. 22 ifadenin 8'i psiko-sosyal belirtiler boyutunu, 7'si fizyolojik belirtiler boyutunu ve 7'si ise işe yönelik belirtiler boyutunu temsil etmektedir.

$\mathrm{Bu}$ doğrultuda araştırmaya katılan banka çalışanlarının ankette yer alan ifadelere katılım düzeylerini ölçmek amacıyla 5'li Likert ölçümü kullanılmıştır. Ölçekteki sıklık dereceleri: 1 . Hiçbir Zaman, 2. Bazen, 3. Kararsızım, 4. Çoğunlukla, 5. Her Zaman olarak etiketlenmiştir.

Araştırmadan elde edilen veriler "SPSS 22 for Windows" paket programina girilerek gerekli analizlerin yapılması için uygun bir şekilde hazırlanmıştır. Bu veriler ile birlikte çalışanların demografik özelliklerine ilişkin frekans analizi yapılmıştır. Daha sonra ise yıldırma davranışlarının ve etkilerinin çalışanların demografik özelliklerine göre anlamlı bir farklılık 
oluşturup oluşturmadıklarının belirlenebilmesi için Mann Whitney U testi ve Kruskal-Wallis testi uygulanmıştır.

\subsection{Araştırmanın Hipotezleri}

Araştırma kapsamında oluşturulan hipotezlere aşağıda yer verilmiştir. Elde edilen veriler doğrultusunda öne sürülen hipotezlere ilişkin analizler hipotez testleri bölümünde incelenecektir. Buna göre araştırmanın hipotezleri şöyledir:

Hı: Banka çalışanlarının medeni durumu ile yıldırmanın psiko-sosyal etkilerine maruz kalma düzeyleri arasında istatistiksel olarak anlamlı bir farklılık vardır.

H2: Banka çalışanlarının yaşı ile yıldırmanın fizyolojik etkilerine maruz kalma düzeyleri arasında istatistiksel olarak anlamlı bir farklılık vardır.

$\mathbf{H}_{3}$ : Banka çalışanlarının pozisyonu ile yıldırmanın psiko-sosyal etkilerine maruz kalma düzeyleri arasında istatistiksel olarak anlamlı bir farklılık vardır.

H4: Banka çalışanlarının pozisyonu ile yıldırmanın fizyolojik etkilerine maruz kalma düzeyleri arasında istatistiksel olarak anlamlı bir farklılık vardır.

H5: Banka çalışanlarının pozisyonu ile yıldırmanın işe yönelik etkilerine maruz kalma düzeyleri arasında istatistiksel olarak anlamlı bir farklılık vardır.

H6: Banka çalışanlarının pozisyonu ile yıldırma davranışlarına maruz kalma düzeyleri arasında istatistiksel olarak anlamlı bir farklılık vardır.

\subsection{Araştırma Bulgularının Değerlendirilmesi}

Bu bölümde araştırmada kullanılan yıldırma davranışları ve yıldırmanın belirtileri ölçeğine ilişkin güvenilirlik analizi, araştırmada kullanılan örneklem hakkındaki demografik bilgilerin belirlenebilmesi için frekans analizi ve elde edilen veriler ile ilgili tanımlayıcı istatistiklere yer verilmiştir. Daha sonra ise araştırma kapsamında oluşturulan hipotezlerin test sonuçları değerlendirilmiştir.

\subsection{1. Ölçeklerin Güvenilirliğine İlişkin Bulgular}

Güvenirliğin test edilmesi amacıyla en sık kullanılan yöntem Cronbach's Alpha katsayısıdır. Hesaplanan güvenilirlik katsayısının 0,70 ve daha üzeri bir puana sahip olması testin güvenilir olduğunu söylemek için genel olarak yeterli görülmektedir (Zorlu, 2017: 86). Dolayısıyla araştırmada kullanılan ölçeğin güvenilirliğini test etmek amacıyla Cronbach's Alpha iç tutarlılık katsayısı analiz edilmiştir. Cronbach Alpha katsayısı, ölçekte yer alan maddenin varyansları toplamının genel varyansa oranlanması ile bulunan bir ağırlıklı standart değişim ortalamasıdır (Ercan ve Kan, 2004: 213).

Herhangi bir konuda hazırlanmış bir ölçeğin güvenilirlik durumu; $0.00<\alpha<0,40$ ise ölçek güvenilir değil, $0,40<\alpha<0,60$ ise ölçek düşük güvenilir, $0,60<\alpha<0,80$ ise ölçek oldukça güvenilir, $0,80<\alpha<0,100$ ise ölçek yüksek derecede güvenilir bir ölçek olarak görülmektedir (Üngüren, 2008: 893).

Tablo 2: Yıldırma Davranışları ve Belirtilerine İlişkin Güvenirlilik Analizi 


\begin{tabular}{|c|c|c|c|}
\hline \multicolumn{2}{|r|}{ Yıldırma Davranışları } & 33 & 0,96 \\
\hline \multirow{4}{*}{ 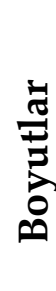 } & Kendini Gösterme ve İletişime Saldırılar & 11 & 0,91 \\
\hline & $\begin{array}{l}\text { Çalışma Kalitesi ve Mesleki Duruma } \\
\text { Saldırılar }\end{array}$ & 9 & 0,92 \\
\hline & İtibar ve Sayginlı̆̆a Saldırılar & 9 & 0,93 \\
\hline & Sağhı̆̆a Dŏgrudan Saldırılar & 4 & 0,92 \\
\hline \multicolumn{2}{|r|}{ Yildırmanin Belirtileri } & 22 & 0,95 \\
\hline \multirow{3}{*}{$\frac{\bar{z}}{\sum_{0}^{3}}$} & Psiko-Sosyal Etkiler & 8 & 0,90 \\
\hline & Fizyolojik Etkiler & 7 & 0,90 \\
\hline & İşe Yönelik Etkiler & 7 & 0,91 \\
\hline
\end{tabular}

Bu çalışmada kullanılan yıldırma anketinin birinci bölümü olan yıldırma davranışlarına ilişkin ifadelerin yer aldığı yıldırma davranışları ölçeği 33 ifadeden oluşmaktadır. Ölçeğe güvenilirlik analizi uygulandığında Cronbach Alfa değeri 0,96 olduğu görülmektedir. Yıldırma davranışlarının alt boyutları incelendiğinde ise 11 ifadeden oluşan kendini gösterme ve iletişime saldırılar boyutunun Cronbach Alfa değeri 0,91'dir. 9 ifadeden oluşan çalışma kalitesi ve mesleki duruma saldırılar boyutunun Cronbach Alfa değeri 0,92'dir. 9 ifadeden oluşan itibar ve saygınlığa saldırılar boyutunun Cronbach Alfa değeri 0,93'tür. Son olarak ise 4 ifadeden oluşan sağlığa doğrudan saldırılar boyutunun Cronbach Alfa değeri 0,92 'dir. Buna göre ölçekte yer alan ifadelere ilişkin yapılan analizlere göre ölçeklerin oldukça güvenirlik olduğu görülmektedir.

Yıldırma anketinin ikinci bölümünü oluşturan yıldırmanın etkileri ölçeği 4 boyuttan ve 22 ifadeden oluşmaktadır. Yıldırmanın belirtileri ölçeğine güvenilirlik analizi uygulandığında Cronbach Alfa değerinin 0,95 olduğu görülmektedir. Yıldırmanın etkilerinin alt boyutlarının güvenirliklerine ilişkin yapılan analizler incelendiğinde ise 8 ifadeden oluşan psiko-sosyal etkiler boyutunun Cronbach Alfa değeri 0,90 olarak hesaplanmıştır. 7 ifadeden oluşan fizyolojik etkiler boyutunun Cronbach Alfa değerinin 0,90 ve yine 7 ifadeden oluşan işe yönelik etkiler boyutunun Cronbach Alfa değerinin ise 0,91 olduğu sonucuna varılmıştır. Buna göre ölçekte yer alan ifadelerin güvenilir olduğu görülmektedir. Ayrıca Bayrak Kök vd. (2014) tarafından yapılan çalışmada da Yousef, Houfey ve Elserogy (2013) anketi kullanılmış ve güvenirlilik analizine göre 0,05 anlamlılık düzeyinde ölçeğin Cronbach Alfa değeri 0,97 olarak hesaplanmıştır. Dolayısıyla araştırmada kullanılan ölçeklerin önceki çalışmalarda da görüldüğ̈ gibi güvenilir olduğu belirtilebilir.

\subsubsection{Katılımcıların Demografik Özellikleri}

Araştırmanın bu bölümünde Denizli ilindeki banka çalışanları hakkındaki bilgilere yer verilmiştir. Banka çalışanlarına anket yöntemiyle yöneltilen demografik bilgilere ilişkin sorular frekans analizi ile değerlendirilmiştir. Ankette yer alan demografik bilgiler; çalışılan bankanın sektörü, cinsiyet, medeni durum, yaş, eğitim durumu, iş hayatında geçirilen toplam süre, mevcut işyerindeki çalışma süresi ve son olarak iş yerindeki pozisyonu şeklindedir. Bu doğrultuda yapılan analizlere ilişkin elde edilen sonuçlar Tablo 3 'te verilmiştir. 
Tablo 3: Demografik Değişkenlere İlişkin Frekans Analizi

\begin{tabular}{|c|c|c|c|c|c|c|c|}
\hline Değişkenler & Gruplar & $\mathrm{n}$ & $\%$ & Değişkenler & Gruplar & $\mathrm{n}$ & $\%$ \\
\hline \multirow[b]{2}{*}{ Banka sektörü } & Kamu & 76 & 48,7 & \multirow{2}{*}{ Cinsiyet } & Erkek & 71 & 45,5 \\
\hline & Özel & 80 & 51,3 & & Kadın & 85 & 54,5 \\
\hline \multirow{2}{*}{ Medeni durum } & Evli & 87 & 55,8 & \multirow{3}{*}{ Eğitim } & Ön lisans & 24 & 15,4 \\
\hline & Bekâr & 69 & 44,2 & & Lisans & 106 & 67,9 \\
\hline \multirow{4}{*}{ Yaş } & $21-25$ & 24 & 15,4 & & Lisansüstü & 26 & 16,7 \\
\hline & $26-30$ & 46 & 29,5 & \multirow{3}{*}{ Pozisyon } & Ast & 84 & 53,8 \\
\hline & $31-35$ & 50 & 32,1 & & $\begin{array}{l}\text { Alt düzey } \\
\text { yönetici }\end{array}$ & 42 & 26,9 \\
\hline & $\begin{array}{l}35^{\prime} \text { ten } \\
\text { büyük }\end{array}$ & 36 & 23,1 & & $\begin{array}{l}\text { Orta ve üst } \\
\text { düzey yönetici }\end{array}$ & 30 & 19,2 \\
\hline \multirow{4}{*}{$\begin{array}{l}\text { İş hayatında geçen } \\
\text { toplam süre }\end{array}$} & 1 y1ldan az & 9 & 5,8 & \multirow{4}{*}{$\begin{array}{l}\text { Mevcut işyerindeki } \\
\text { çalışma süresi }\end{array}$} & 1 yıldan az & 27 & 17,3 \\
\hline & $1-5$ y1l & 49 & 31,4 & & $1-5$ y1l & 73 & 46,8 \\
\hline & 6-10 y1l & 51 & 32,7 & & 6-10 yıl & 33 & 21,2 \\
\hline & $\begin{array}{l}10 \text { yıldan } \\
\text { fazla }\end{array}$ & 47 & 30,3 & & 10 yıldan fazla & 23 & 14,7 \\
\hline
\end{tabular}

Demografik veriler incelendiğinde çalışanların \%48,7'si kamu bankalarında, \%51,3'ü ise özel bankalarda çalışmaktadır. Çalışanların \%45,5'i erkek, \%54,5'i ise kadın; \%55,8'i evli ve \%44,2'si bekârdır. Bununla birlikte çalışanların \%15,4'ü 21-25 yaş aralığında, \%29,5'i 26-30 yaş aralığında, \%32,1'i 31-35 yaş aralığında ve \%23,1'i ise 35 yaşından büyüktür. Eğitim düzeylerine göre $\% 15,4^{\prime}$ ü ön lisans, $\% 67,9^{\prime} u$ lisans ve $\% 16,7^{\prime}$ si ise lisansüstü mezunudur. Çalışanların \%53,8'i ast, \%26,9'u alt düzey yönetici ve $\% 19,2$ 'si orta ve üst düzey yönetici pozisyonunda görev almaktadırlar. İş hayatındaki tecrübelerine bakıldığında \%5,8'i 1 yıldan az, \%31,4'ü 1-5 yıl, \%32,7'si 6-10 yıl ve \%30,3'ü 10 yıldan fazla bir süredir iş hayatındadır. Diğer taraftan \%17,3'ü 1 yıldan az, \%46,8'i 1-5 yıl, \%21,2'si 6-10 yıl ve \%14,7'si 10 yıldan fazla zamandır mevcut işyerlerinde çalışmaktadır.

\subsubsection{Tanımlayıcı İstatistikler}

Araştırmanın bu bölümünde yıldırma davranışları ve yıldırmanın etkilerine ait ifadelerin ortalama ve standart sapmaları elde edilen veriler doğrultusunda incelenmiştir. Tablo 4 'te yıldırma davranışlarının ortalamalarına ait tanımlayıcı analizlere ilişkin yapılan analizlerin sonuçlarına yer verilmiştir. Tablo $4^{\prime}$ teki verilere göre araştırmada kullanılan yıldırma davranışları ölçeğinde yer alan kendini gösterme ve iletişime saldırılar, çalışma kalitesi ve mesleki konuma saldırılar, itibar ve saygınlığa saldırılar ve sağlığa doğrudan saldırılar boyutlarında yıldırma davranışlarının çalışanlar arasında düşük düzeyde görüldüğü sonucuna varılmıştır.

Verilerin değerlendirilebilmesi için ortalamalar, aldıkları değerlere göre düşük, orta ve yüksek olmak üzere üç düzeyde gruba bölünmüş̧ür. Bu düzeylere dâhil olan ortalamaların dağ1lımı şu şekildedir: $\bar{x}=1-2,59$ : Düşük; $\bar{x}=2,60-3,39$ : Orta; $\bar{x}=3,40-5$ : Yüksek 


\section{Tablo 4: Yıldırma Davranışlarına İlişkin Bulgular}

\begin{tabular}{|c|c|c|c|}
\hline & $\bar{x}$ & Std. Sap. & Düzey \\
\hline Kendini Gösterme ve İletişime Saldırılar & 1,78 & 0,67 & Düşük \\
\hline Size işyerinde yokmuşsunuz gibi davranılır ya da görmezden gelinirsiniz. & 1,85 & 0,97 & Düşük \\
\hline Görüşme ve konuşma taleplerinize karşılık verilmez. & 1,73 & 0,93 & Düşük \\
\hline Gönderdiğiniz yazılı ve elektronik postalarınıza cevap verilmez. & 1,80 & 1,02 & Düşük \\
\hline $\begin{array}{l}\text { Sorumlu olduğunuz görevler sizden alınarak sizden daha düşük pozisyondaki } \\
\text { birine verilir. }\end{array}$ & 1,73 & 0,88 & Düşük \\
\hline Kendinizi kanıtlamanız için size fırsat verilmez. & 1,81 & 0,94 & Düşük \\
\hline Düzenlenen sosyal sosyal etkinlikler hakkında size bilgi verilmez. & 1,75 & 0,87 & Düşük \\
\hline Tavsiyeleriniz ve kararlarınız eleştirilir ve reddedilir. & 1,81 & 0,85 & Düşük \\
\hline Sizden daha düşük pozisyondaki insanlar tarafından denetlenirsiniz. & 1,58 & 0,81 & Düşük \\
\hline Konuştuğunuz zaman sözleriniz sık sık kesilir. & 1,92 & 0,93 & Düşük \\
\hline İşiniz için gerekli olan bilgi, belge ve materyaller sizden saklanır. & 1,79 & 0,96 & Düşük \\
\hline İstifa etmeniz ya da pozisyonunuzu değiştirmeniz için size baskı yapılır. & 1,81 & 0,97 & Düşük \\
\hline Çalışma Kalitesi ve Mesleki Duruma Saldırılar & 2,09 & 0,81 & Düşük \\
\hline İşiniz ve işinizden elde ettikleriniz ile ilgili sürekli kusur/hata bulunur. & 2,01 & 1,03 & Düşük \\
\hline Yapabileceğinizden daha fazla işten sorumlu tutulursunuz. & 2,19 & 1,08 & Düşük \\
\hline $\begin{array}{l}\text { Başkaları tarafından yapılan işlerin olumsuz sonuçlarından yalnızca siz sorumlu } \\
\text { tutulursunuz. }\end{array}$ & 2,06 & 1,03 & Düşük \\
\hline Sorumluluğunuzda olmayan işlere karşı suçlanırsınız. & 2,01 & 0,96 & Düşük \\
\hline Yaptığınız her iş için profesyonel yetenekleriniz sorgulanır. & 2,10 & 1,07 & Düşük \\
\hline Yaptığınız işler değersiz ve önemsiz görülür. & 2,16 & 1,02 & Düşük \\
\hline Performansınız sürekli olarak olumsuz yönde değerlendirilir. & 2,12 & 1,02 & Düşük \\
\hline Sanki siz ve işiniz denetleniyormuş gibi hissettirilir. & 2,19 & 1,08 & Düşük \\
\hline Özgüveninizi olumsuz yönde etkileyecek bir işi yapmak zorunda bırakılırsınız. & 1,98 & 0,97 & Düşük \\
\hline İtibar ve Saygınlığa Saldırılar & 1,79 & ,70 & Düşük \\
\hline Yumruğun masaya vurulması gibi davranışlarla karşı karşıya kalırsınız. & 1,70 & 0,90 & Düşük \\
\hline Hakkınızda asılsız söylentiler yapılır. & 1,92 & 0,92 & Düşük \\
\hline Sözlü olarak tehdit edilirsiniz. & 1,96 & 0,96 & Düşük \\
\hline Başkalarının yanında sizinle ilgili aşağılayıcı ve onur kırıcı bir şekilde konuşulur. & 1,81 & 0,90 & Düşük \\
\hline Başkalarının yanında size karşı küçümseyici davranışlar kullanılır. & 1,78 & 0,84 & Düşük \\
\hline Özel hayatınızla ilgili asılsız söylentiler ortaya atılır. & 1,74 & 0,87 & Düşük \\
\hline Akıl sağlığınızın yerinde olmadığı iddia edilir. & 1,64 & 0,86 & Düşük \\
\hline Dürüstlüğünüz ve güvenirliliğiniz sorgulanır. & 1,81 & 0,88 & Düşük \\
\hline Sizinle ilgili adil olmayan raporlar yazılır. & 1,72 & 0,88 & Düşük \\
\hline Sağlığa Doğrudan Saldırılar & 1,72 & ,83 & Düşük \\
\hline Size karşı fiziksel şiddet uygulanır. & 1,69 & 0,93 & Düşük \\
\hline Kişisel eşyalarınıza zarar verilir. & 1,67 & 0,90 & Düşük \\
\hline Siz bir iş ortama girdiğinizde kasıtlı olarak orası terk edilir. & 1,79 & 0,95 & Düşük \\
\hline Çalışma arkadaşlarınızın sizinle konuşması engellenir ya da yasaklanır. & 1,72 & 0,91 & Düşük \\
\hline
\end{tabular}

Tablo 5 'te ise yıldırmanın etkilerine ait ifadelere ilişkin tanımlayıcı analizlere yer verilmiştir. Tablo 5'teki veriler dikkate alındığında yıldırmanın etkileri ölçeğine ait üç boyutta da çalışanların maruz kaldıkları yıldırma davranışlarının oluşturduğu belirtilerin düşük düzeyde görüldüğü sonucuna varılmıştır.

\section{Tablo 5: Yıldırmanın Etkileri Ölçeğine İlişkin Bulgular}

\begin{tabular}{|l|c|c|c|}
\hline & $\bar{x}$ & Std. Sap. & Düzey \\
\hline Psiko-Sosyal Etkiler & 2,26 & 0,77 & Düşük \\
\hline
\end{tabular}




\begin{tabular}{|l|l|l|l|}
\hline Kendime karşı öz güvenimde ve saygımda azalma hissediyorum. & 2,19 & 0,99 & Düşük \\
\hline İşyerimdeki hiç kimseye güvenmiyorum. & 2,48 & 1,06 & Düşük \\
\hline Yalnızlık hissediyorum. & 2,33 & 0,99 & Düşük \\
\hline Çoğu zaman kendimi suçlu hissediyorum. & 2,18 & 1,04 & Düşük \\
\hline Kötü bir şey olacağına dair açıklanamayan bir korku yaşıyorum & 2,16 & 0,97 & Düşük \\
\hline Bu durum iş dışındaki hayatımı olumsuz etkiliyor. & 2,24 & 1,07 & Düşük \\
\hline Maruz kaldığım davranışlardan dolayı bir psikolojik destek alıyorum. & 1,95 & 0,93 & Düşük \\
\hline Kendimi stresli ve yorgun hissediyorum. & 2,57 & 1,05 & Düşük \\
\hline Fizyolojik Etkiler & 2,09 & $\mathbf{0 , 8 1}$ & Düşük \\
\hline Kan basıncımda değişiklikler yaşıyorum. & 1,99 & 0,94 & Düşük \\
\hline Ya aşarı yemek yemek istiyorum ya da iştahsızım. & 2,08 & 1,05 & Düşük \\
\hline Göğüs ağrısı ve kalp çarpıntısı yaşıorum. & 1,99 & 0,98 & Düşük \\
\hline Baş ağrısı çekiyorum. & 2,54 & 1,07 & Düşük \\
\hline Mide ve bağırsak şikâyetlerim var. & 2,10 & 1,07 & Düşük \\
\hline Kontrol dişı hareketlerim/tiklerim gelişti. & 1,96 & 0,97 & Düşük \\
\hline Sigara veya ilaç (madde bağımlılığı) kullanmaya başladım. & 1,96 & 1,12 & Düşük \\
\hline İşe Yönelik Etkiler & $\mathbf{2 , 3 1}$ & $\mathbf{0 , 8 3}$ & Düşük \\
\hline İşime karşı daha az bağlılık hissediyorum. & 2,34 & 1,01 & Düşük \\
\hline Bir şeyler yapılması gerektiğinde çok yavaş hareket ediyorum. & 2,13 & 0,92 & Düşük \\
\hline İşimde bazı hatalar yapıyorum. & 2,25 & 0,87 & Düşük \\
\hline Bir işe konsantre olmakta zorluk çekiyorum. & 2,30 & 1,02 & Düşük \\
\hline İşyerimde hiçbir işi yapmak istemiyorum. & 2,33 & 1,03 & Düşük \\
\hline Çoğu zaman işe gelmek istemiyorum. & 2,36 & 1,12 & Düşük \\
\hline İsyerinde çalışma arkadaşlarımla çatışma yaşıyorum. & 2,43 & 1,15 & Düşük \\
\hline
\end{tabular}

\subsubsection{Hipotez Testleri}

$\mathrm{Bu}$ bölümde banka çalışanlarından elde edilen verilere dayanarak çalışanların demografik özelliklerinin yıldırma davranışları ve yıldırmanın etkileri üzerinde anlamlı bir farklılık oluşturup oluşturmadıkları incelenmiştir. Bu nedenle araştırmada yer alan hipotezleri analiz etmek için parametrik olmayan testlerden Mann Whitney U testi uygulanacaktır. Bu test farklılıkları incelemeye yönelik parametrik olmayan analiz tekniklerindendir. Bu teknikle demografik değişkenlere ilişkin farklılıklar incelenecektir. Sonuçlara göre anlamlılık düzeyine bakılarak $\mathrm{p}<0,05$ olması halinde anlamlı bir farklılık vardır sonucuna varılabilmektedir.

\subsubsection{1. Çalışılan Sektöre Göre Yıldırmanın Değerlendirilmesi}

Tablo 6'da yıldırma davranışları ve yıldırmanın etkilerinin banka sektörü değişkenine göre anlamlı bir farklılık oluşturup oluşturmadığı incelenmiştir. Bu verilere göre çalışılan bankanın sektörü ile psiko-sosyal etkiler $(\mathrm{p}=0,772)$, fizyolojik etkiler $(0,089)$, işe yönelik etkiler $(\mathrm{p}=0,318)$ ve yıldırma davranışları $(\mathrm{p}=0,619)$ arasında anlamlı bir farklılık bulunamamıştır.

Tablo 6: Sektörlere Göre Farklılık Analizi

\begin{tabular}{|l|r|r|r|r|}
\hline & $\begin{array}{c}\text { Psiko-Sosyal } \\
\text { Etkiler }\end{array}$ & Fizyolojik Etkiler & $\begin{array}{c}\text { İşe Yönelik } \\
\text { Etkiler }\end{array}$ & $\begin{array}{c}\text { Ylldırma } \\
\text { Davranışlar }\end{array}$ \\
\hline Mann Whitney U & 2958,500 & 2562,000 & 2759,000 & 2900,000 \\
\hline Wilcoxon W & 5884,500 & 5802,000 & 5999,000 & 6140,000 \\
\hline Z &,- 289 & $-1,699$ &,- 999 &,- 497 \\
\hline
\end{tabular}




\begin{tabular}{|l|r|r|r|r|}
\hline Anlamlılık (p) &, 772 &, 089 &, 318 &, 619 \\
\hline
\end{tabular}

Karcıoğlu ve Çelik (2012: 68) tarafından banka çalışanları üzerinde yapılan çalışmada yıldırmanın görev yapılan bankanın türüne göre farklılık göstermediği sonucuna varılmıştır. Elde edilen sonuçlar incelendiğinde Karcıoğlu ve Çelik (2012) tarafından yapılan çalışmanın sonuçları Tablo 6'daki sonuçlar ile benzerlik göstermektedir. Ayrıca Özdemir vd., (2012: 139) yapmış olduğu çalışmada çalışılan bankanın sektörüne göre yıldırma ve alt boyutlarına ilişkin farklılığı belirlemek amacıyla Mann-Whitney U Testi uygulamış ve anlamlı bir farklılığın söz konusu olmadığı sonucuna vardır. Dolayısıyla literatürde yapılan çalışmalar dikkate alındığında ulaşılan sonuçların önceki çalışmalar tarafından desteklendiği ve yapılan çalışmaların benzer sonuçlar gösterdiği anlaşılmaktadır.

\subsubsection{2. Çalışanların Cinsiyetlerine Göre Yıldırmanın Değerlendirilmesi}

Tablo 7'de yıldırma davranışları ve yıldırmanın etkilerinin cinsiyet değişkenine anlamlı bir farklığa yol açıp açmadığına yönelik yapılan Mann Whitney U Testine ilişkin sonuçlar bulunmaktadır. Elde edilen sonuçlara göre $\% 5$ anlamlılık düzeyinde cinsiyet ile psiko-sosyal etkiler $(p=0,239)$, fizyolojik etkiler $(p=0,669)$, işe yönelik etkiler $(p=0,404)$ ve yıldırma davranışları $(\mathrm{p}=0,678)$ arasında anlamlı bir farklılık olmadığı görülmektedir.

Tablo 7: Cinsiyete Göre Farklılık Analizi

\begin{tabular}{|l|r|r|r|r|}
\hline & \multicolumn{1}{|c|}{$\begin{array}{c}\text { Psiko-Sosyal } \\
\text { Etkiler }\end{array}$} & $\begin{array}{c}\text { Fizyolojik } \\
\text { Etkiler }\end{array}$ & $\begin{array}{c}\text { İşe Yönelik } \\
\text { Etkiler }\end{array}$ & \multicolumn{1}{c|}{$\begin{array}{c}\text { Yıldırma } \\
\text { Davranışları }\end{array}$} \\
\hline Mann Whitney U & 2687,500 & 2897,500 & 2783,500 & 2901,000 \\
\hline Wilcoxon W & 6342,500 & 5453,500 & 6438,500 & 6556,000 \\
\hline Z & $-1,176$ &,- 428 &,- 835 &,- 415 \\
\hline Anlamlılı (p) &, 239 &, 669 &, 404 &, 678 \\
\hline
\end{tabular}

Benzer sonuçlar Çoban ve Nakip (2007: 313) tarafından bankacılık sektöründeki çalışanlar üzerinde yapılan çalışmada da elde edilmiştir. Bununla birlikte Palaz'ın (2016: 29) Bursa ve Bandırma illerinde yapmış olduğu çalışmada çalışanların cinsiyetlerine ilişkin yapılan Mann-Whitney U testine göre anlamlı bir farklılık bulunmamıştır. Dolayısıyla yıldırma davranışlarının ve etkilerinin banka çalışanlarının cinsiyetine göre anlamlı bir farklılık oluşturmaması önceki çalışmaların sonuçları ile desteklenmektedir.

Buna karşılık Leymann (1996: 175) tarafından yapılan çalışmada ise cinsiyete göre anlamlı bir farklılığın olduğu ve kadınların erkeklere göre daha yüksek ortalamaya sahip olduğu sonucuna ulaşılmıştır. Ayrıca Aşkın ve Aşkın (2018: 277) da kadınların gösterdikleri ortalamanın erkeklere göre yüksek çıktığını nitel araştırma yöntemiyle bankacılık sektöründe yapmış olduğu bir çalışmada ifade etmiştir.

\subsubsection{Medeni Duruma Göre Yıldırmanın Değerlendirilmesi}

Tablo 8'de görüldüğü gibi medeni durum değişkenine göre yıldırma davranışları ve yıldırmanın etkileri arasında anlamlı bir farklılık olup olmadı̆̆ı incelenmiştir. Yapılan analizlere bakıldığında sadece psiko-sosyal etkiler boyutunun anlamlılık düzeyi $p<0,05^{\prime}$ ten küçük çıkmıştır. Bu sonuca göre medeni durum ile psiko-sosyal etkiler boyutu $(p=0,036)$ arasında anlamlı bir farklılık vardır. Dolayısıyla araştırmanın hipotezlerinden biri olan $\mathrm{H}_{1}$ hipotezi 0,05 anlamlılık düzeyinde desteklenmektedir. Diğer taraftan medeni durum ile 
fizyolojik etkiler $(p=0,151)$, işe yönelik etkiler $(0,070)$ ve yıldırma davranışları $(p=0,256)$ arasında anlamlı bir farklılık bulunamamıştır.

Tablo 8: Medeni Duruma Göre Farklılık Analizi

\begin{tabular}{|l|r|r|r|r|}
\hline & $\begin{array}{c}\text { Psiko-Sosyal } \\
\text { Etkiler }\end{array}$ & $\begin{array}{c}\text { Fizyolojik } \\
\text { Etkiler }\end{array}$ & $\begin{array}{c}\text { İşe Yönelik } \\
\text { Etkiler }\end{array}$ & \multicolumn{1}{c|}{$\begin{array}{c}\text { Yıldırma } \\
\text { Davranışları }\end{array}$} \\
\hline Mann Whitney U & 2414,000 & 2600,000 & 2494,500 & 2683,500 \\
\hline Wilcoxon W & 6242,000 & 6428,000 & 6322,500 & 6511,500 \\
\hline Z & $-2,100$ & $-1,436$ & $-1,814$ & $-1,135$ \\
\hline Anlamlılık (p) &, 036 &, 151 &, 070 &, 256 \\
\hline
\end{tabular}

Kesebir (2018: 161) İstanbul ilindeki banka çalışanları üzerinde yapmış olduğu çalışmada yıldırmanın medeni durum değişkenine göre anlamlı bir farklılık oluşturduğu sonucuna varılmıştır. Sonuç olarak bakıldığında Kesebir'in (2018) psiko-sosyal etkiler boyutunun dışındaki diğer boyutlar açısından elde edilen sonuçlar ile farklılaşmaktadır. Aslım ve Yaşar'ın (2016: 33) yapmış olduğu çalışmada çalışanların medeni durumu yıldırma üzerinde istatistiksel olarak anlamlı bir farklılık oluşturmadı̆̆ı sonucuna varılmıştır. Önceki çalışmalarda elde edilen sonuçlar göz önüne alındığında Tablo 8'deki sonuçlar ile benzerlik gösterdiği anlaşılmaktadır.

Psiko-sosyal etkiler boyutundaki anlamlı farklılıklara ilişkin elde edilen veriler Tablo 9'da verilmiştir.

Tablo 9: Medeni Duruma Göre Ortalama Farklar

\begin{tabular}{|l|l|l|}
\hline & Medeni Durum & Ortalama \\
\hline \multirow{2}{*}{ Psiko-Sosyal Etkiler } & Evli & 2,15 \\
\cline { 2 - 3 } & Bekâr & 2,41 \\
\hline
\end{tabular}

Farklılıklar tablosu incelendiğinde anlamlı fark bulunan psiko-sosyal etkiler boyutunda bekâr çalışanların $(\bar{x}=2,41)$ evli çalışanlara $(\bar{x}=2,15)$ göre daha fazla psiko-sosyal etkilere maruz kaldıkları görülmektedir.

Çalışılan banka sektörü, cinsiyet ve medeni durum değişkenlerinde iki ifade kıyaslandığı için Mann Whitney U testi uygulanmıştır. Ancak araştırmanın diğer değişkenleri olan yaş, eğitim durumu, iş hayatında geçen toplam süre, mevcut iş yerindeki çalışma süresi ve pozisyon değişkenleri incelenecektir. Bu değişkenlerdeki farklılıkları incelemek için parametrik olmayan testlerde kullanılan Kruskal-Wallis Testi kullanılacaktır.

\subsubsection{4. Çalışanların Yaşına Göre Yıldırmanın Değerlendirilmesi}

Tablo 10 incelendiğinde yaş değişkeni ile yıldırma davranışları ve yıldırmanın etkileri boyutları arasında fizyolojik etkiler boyutu dışında anlamlı bir farklılık bulunamamıştır. Fizyolojik etkiler boyutunda ortaya çıkan anlamlılık düzeyi $\mathrm{p}<0,05$ 'ten küçük olarak bulunmuştur. Buna göre yaş ile fizyolojik etkiler boyutu $(p=0,026)$ arasında anlamlı bir farklılık varken psiko-sosyal etkiler $(p=0,119)$, işe yönelik etkiler $(p=0,088)$ ve yıldırma davranışları $(\mathrm{p}=0,093)$ arasında anlamlı bir farklılık yoktur. Bu verilere göre araştırmanın hipotezlerinden biri olan yaş ile fizyolojik etkiler boyutu arasındaki farklılığa ilişkin oluşturulan $\mathrm{H}_{2}$ hipotezi 0,05 anlamlılık düzeyinde desteklenmektedir. 
Tablo 10: Yaşa Göre Farklılık Analizi

\begin{tabular}{|l|c|c|c|c|}
\hline & $\begin{array}{c}\text { Psiko-Sosyal } \\
\text { Etkiler }\end{array}$ & $\begin{array}{c}\text { Fizyolojik } \\
\text { Etkiler }\end{array}$ & $\begin{array}{c}\text { İşe Yönelik } \\
\text { Etkiler }\end{array}$ & $\begin{array}{c}\text { Yıldırma } \\
\text { Davranışları }\end{array}$ \\
\hline Ki-kare & 5,850 & 9,255 & 6,550 & 6,415 \\
\hline Df & 3 & 3 & 3 & 3 \\
\hline Anlamlılık (p) &, 119 &, 026 &, 088 &, 093 \\
\hline
\end{tabular}

Karsavuran'ın (2014: 284) yapmış olduğu çalışmada elde edilen sonuçlar bu çalışmaya göre ise yaş değişkenine göre yıldırmanın tüm boyutlarında anlamlı bir farklılık bulunmuştur. Yine benzer sonuçlar Köse ve Uysal (2010: 271) tarafından yapılan çalışmada elde edilmiştir. Bu çalışmanın sonuçlarına göre yaş değişkeni yıldırma boyutları üzerinde istatistiksel olarak anlamlı bir farklılık oluşturmamaktadır. Dolayısıyla önceki çalışmalarda elde edilen sonuçlar bu çalışmadaki fizyolojik etkiler boyutunda ulaşılan sonuçlar dışındaki diğer bulgular ile paralellik göstermektedir.

Fizyolojik etkiler boyutundaki anlamlı farklılıklara ilişkin elde edilen veriler Tablo 11'de verilmiştir.

Tablo 11: Yaşa Göre Ortalama Farklar

\begin{tabular}{|l|c|c|}
\hline & Yaş & Ortalama \\
\hline \multirow{4}{*}{ Fizyolojik Etkiler } & $21-25$ & 2,01 \\
\cline { 2 - 3 } & $26-30$ & 2,37 \\
\cline { 2 - 3 } & $31-35$ & 2,05 \\
\cline { 2 - 3 } & $35^{\prime}$ ten büyük & 1,84 \\
\hline
\end{tabular}

Farklılıklar tablosuna bakıldığında anlamlı fark bulunan fizyolojik etkiler boyutunda 26-30 $(\bar{x}=2,37)$ yaş grubunun diğer yaş gruplarına göre daha fazla fizyolojik etkilere maruz kaldıkları görülmektedir.

\subsubsection{Eğitim Durumuna Göre Yıldırmanın Değerlendirilmesi}

Tablo 12' de çalışanların eğitim durumu ile yıldırma davranışları ile yıldırmanın etkiler boyutları arasındaki farklılığa ilişkin 0,05 anlamlılık düzeyinde incelenen Kruskal-Wallis Testi'nin sonuçları yer almaktadır. Elde edilen sonuçların hepsinde de anlamlılık düzeyi 0,05 ten büyük çıkmıştır. Buna göre eğitim durumu ile psiko-sosyal etkiler $(p=0,052)$, fizyolojik etkiler $(p=0,130)$, işe yönelik etkiler $(p=0,115)$ ve yıldırma davranışları $(p=0,119)$ arasında anlamlı bir farklılık bulunmamaktadır.

Tablo 121: Eğitim Düzeyine Göre Farklılık Analizi

\begin{tabular}{|l|c|c|c|c|}
\hline & $\begin{array}{c}\text { Psiko-Sosyal } \\
\text { Etkiler }\end{array}$ & $\begin{array}{c}\text { Fizyolojik } \\
\text { Etkiler }\end{array}$ & $\begin{array}{c}\text { İşe Yönelik } \\
\text { Etkiler }\end{array}$ & $\begin{array}{c}\text { Yıldırma } \\
\text { Davranışları }\end{array}$ \\
\hline Ki-kare & 5,924 & 4,077 & 4,330 & 4,261 \\
\hline Df & 2 & 2 & 2 & 2 \\
\hline Anlamlılık (p) &, 052 &, 130 &, 115 &, 119 \\
\hline
\end{tabular}

Elde edilen bulgular incelendiğinde Bayrak Kök vd. (2014: 56) tarafından eğitim düzeyi değişkenine ilişkin elde edilen sonuçlar Tablo 12'deki sonuçları destekler niteliktedir. Bununla birlikte Karabal vd. (2016: 156) yapmış oldukları çalışmada çalışanların eğitim düzeyi ile yıldırma ve boyutları arasında anlamlı bir farklılık olup olmadığını incelemiştir. 
Yapılan incelemeler sonucunda eğitim düzeyine göre yıldırma ve boyutlarında istatistiksel olarak anlamlı bir farklılık olmadığını ifade etmiştir. Dolayısıyla önceki çalışmalarda elde edilen sonuçlar bu çalışmanın sonuçlarını destelemektedir.

\subsubsection{6. İş Hayatında Geçirilen Süreye Göre Yıldırmanın Değerlendirilmesi}

Tablo 13'te çalışanların iş hayatında geçirdikleri süreye göre yıldırma davranışları ve yıldırmanın etkileri arasında anlamlı bir farklılık olup olmadığı incelenmiştir. Tablo 13 'teki veriler incelendiğinde değişkenlerin anlamlılık düzeyinin $\mathrm{p}<0,05$ ten büyük olduğu görülmektedir. $\mathrm{Bu}$ sonuçlara göre iş hayatında geçirilen süre ile psiko-sosyal etkiler $(p=0,587)$, fizyolojik etkiler $(p=0,474)$, işe yönelik etkiler $(p=0,808)$ ve yıldırma davranışları $(\mathrm{p}=0,162)$ arasında anlamlı bir farklılık bulunmamaktadır.

Tablo 213: İş Hayatında Geçirilen Süreye Göre Farklılık Analizi

\begin{tabular}{|l|c|c|c|c|}
\hline & $\begin{array}{c}\text { Psiko-Sosyal } \\
\text { Etkiler }\end{array}$ & $\begin{array}{c}\text { Fizyolojik } \\
\text { Etkiler }\end{array}$ & $\begin{array}{c}\text { İşe Yönelik } \\
\text { Etkiler }\end{array}$ & $\begin{array}{c}\text { Yıldırma } \\
\text { Davranışları }\end{array}$ \\
\hline Ki-kare & 1,932 & 2,510 &, 971 & 5,143 \\
\hline Df & 3 & 3 & 3 & 3 \\
\hline Anlamlılık (p) &, 587 &, 474 &, 808 &, 162 \\
\hline
\end{tabular}

Palaz (2016: 29) çalışanların iş hayatında geçirdiği süreye göre değişkenlere ilişkin anlamlı farklılık olup olmadığına yönelik banka çalışanlarından elde ettiği verilerde Kruskal-Wallis testi uygulamıştır. Bu testin sonuçlarına göre anlamlı bir farklılık bulunamamıştır. Palaz (2016) tarafından elde edilen sonuçlar bu çalışmada elde edilen sonuçlarla örtüşmektedir. Buna karşılık Kesebir (2018: 162) tarafından yapılan çalışmada ise iş hayatından geçen süre değişkenine göre istatistiksel olarak anlamlı bir farklılık bulunmuştur. Bu noktada Kesebir'in (2018) çalışmasındaki sonuçlar bu çalışmadaki sonuçlar ile farklılık göstermektedir.

\subsubsection{Mevcut İşyerindeki Tecrübeye Göre Yıldırmanın Değerlendirilmesi}

Tablo 14'te çalışanların çalıştıkları işyerinde elde ettikleri tecrübe ile yıldırma davranışları ve yıldırmanın etkileri arasındaki farklılığa yönelik Kruskal-Wallis Testi'nden elde edilen sonuçlar bulunmaktadır. Bu tabloya göre 0,05 anlamlılık düzeyinde işyerinde elde edilen tecrübe ile incelenen değişkenler arasında anlamlı bir farklılık yoktur. Buna göre çalışanların işyerinde elde ettikleri tecrübe ile psiko-sosyal etkiler $(p=0,729)$, fizyolojik etkiler $(p=0,268)$, işe yönelik etkiler $(p=0,522)$ ve yıldırma davranışları $(p=0,344)$ arasında anlamlı bir farklılık bulunmamaktadir.

Tablo 14: Mevcut İşyerindeki Tecrübeye Göre Farklılık Analizi

\begin{tabular}{|l|c|c|c|c|}
\hline & $\begin{array}{c}\text { Psiko-Sosyal } \\
\text { Etkiler }\end{array}$ & $\begin{array}{c}\text { Fizyolojik } \\
\text { Etkiler }\end{array}$ & $\begin{array}{c}\text { İşe Yönelik } \\
\text { Etkiler }\end{array}$ & $\begin{array}{c}\text { Yıldırma } \\
\text { Davranışları }\end{array}$ \\
\hline Ki-kare & 1,299 & 3,943 & 2,253 & 3,330 \\
\hline Df & 3 & 3 & 3 & 3 \\
\hline Anlamlılı (p) &, 729 &, 268 &, 522 &, 344 \\
\hline
\end{tabular}

Aslım ve Yaşar (2016: 33) tarafından yapılan çalışmada çalışanların mevcut işyerindeki tecrübelerine göre yıldırma arasında istatistiksel olarak anlamlı bir farklılığın olup olmadığı incelenmiş ve anlamlı bir farklılığın olmadığı sonucuna varılmıştır. Aslım ve Yaşar'ın (2016: 32) elde ettiği sonuçlar Tablo 14'teki sonuçlar ile örtüşmektedir. 


\subsubsection{8. İşyerindeki Pozisyona Göre Yıldırmanın Değerlendirilmesi}

Tablo 15'te çalışanların yer aldıkları pozisyon değişkeni ile yıldırma davranışları ve yıldırmanın etkileri arasındaki farklılığa ilişkin 0,05 anlamlılık düzeyinde incelenen KruskalWallis Testi ile ilgili elde edilen sonuçlara yer verilmiştir. Buna göre çalışanların yer aldıkları pozisyon ile incelenen değişkenlerin hepsinde de anlamlı bir farklılık bulunmuştur. Dolayısıyla çalışanların bulundukları pozisyona göre değişkenlerin anlamlı bir şekilde farklılaştı̆̆ı görülmektedir.

Bu sonuçlara doğrultusunda pozisyon değişkeni ile yıldırma etkilerinin boyutları olan psikososyal etkiler boyutu ( $\mathrm{p}=0,015)$, fizyolojik etkiler boyutu $(\mathrm{p}=0,000)$, işe yönelik etkiler boyutu $(p=0,035)$ ve bir diğer değişken olan yıldırma davranışları $(p=0,000)$ arasında anlamlı bir farklılık bulunmuştur. Sonuç olarak bakıldığında araştırma hipotezleri kapsamında oluşturulan $\mathrm{H}_{3}, \mathrm{H}_{4}, \mathrm{H}_{5}$ ve $\mathrm{H}_{6}$ hipotezleri desteklenmektedir.

Tablo 15: Pozisyona Göre Farklılık Analizi

\begin{tabular}{|l|c|c|c|c|}
\hline & $\begin{array}{c}\text { Psiko-Sosyal } \\
\text { Etkiler }\end{array}$ & $\begin{array}{c}\text { Fizyolojik } \\
\text { Etkiler }\end{array}$ & $\begin{array}{c}\text { İşe Yönelik } \\
\text { Etkiler }\end{array}$ & $\begin{array}{c}\text { Yıldırma } \\
\text { Davranışları }\end{array}$ \\
\hline Ki-kare & 8,444 & 22,492 & 6,719 & 20,456 \\
\hline Df & 2 & 2 & 2 & 2 \\
\hline Anlamlılık (p) &, 015 &, 000 &, 035 &, 000 \\
\hline
\end{tabular}

Karsavuran (2014: 286) tarafından banka çalışanları üzerinde yapılan çalışmada banka çalışanlarının işyerinde görev aldıkları pozisyon değişkenine ilişkin farklılık analizi uygulanmıştır. Karsavuran (2014) tarafından yapılan çalışmada elde edilen sonuçlara göre banka çalışanlarının işyerinde görev aldıkları pozisyonu ile yıldırmanın değişkeninin tüm boyutlarında anlamlı bir farklılık olduğu tespit edilmiştir. Bu sonuçlara bakıldığında Tablo 15 'te görülen sonuçlar ile benzerlik gösterdiği söylenebilir.

Bu konuda yapılan bir diğer çalışma ise Köse ve Uysal (2010: 273) tarafından yapılmıştır. Çalışanların işyerinde bulundukları pozisyonları ile yıldırma boyutları arasında farklılık olup olmadığının incelenmiştir. Yapılan çalışmada elde edilen sonuçlara bakıldığında yıldırmanın tüm boyutlarda anlamlı bir farklılık ortaya çıkmıştır. Görüldüğü gibi Köse ve Uysal (2010) tarafından yapılan çalışmada ulaşılan sonuçlar Tablo 15'teki sonuçlar ile benzerlik göstermekte ve bu çalışmanın sonuçlarını destekler niteliktedir. Dolayısıyla yıldırma konusu ile ilgili olarak literatürde daha önce yapılan çalışmalarda elde edilen sonuçların bu çalışmada ulaşılan sonuçlar ile örtüştüğü ifade edilebilir.

Tablo 16 'da ise ortaya çıkan farklllıklara ilişkin elde edilen sonuçlara yer verilmiş ve bu sonuçlar yorumlanmıştır.

Tablo 16: Pozisyona Göre Ortalama Farklar

\begin{tabular}{|l|c|c|}
\hline \multirow{2}{*}{ Psiko-Sosyal Etkiler } & Pozisyon & $\begin{array}{c}\text { Ortalamaların } \\
\text { S1ralaması }\end{array}$ \\
\hline \multirow{2}{*}{ Fizyolojik Etkiler } & Ast & 2,21 \\
\cline { 2 - 3 } & Alt düzey yönetici & 2,54 \\
\cline { 2 - 3 } & Orta ve üst düzey yönetici & 2,02 \\
\cline { 2 - 3 } & Ast & 1,86 \\
\hline
\end{tabular}




\begin{tabular}{|l|c|c|}
\hline & Orta ve üst düzey yönetici & 2,02 \\
\hline \multirow{3}{*}{ İşe Yönelik Etkiler } & Ast & 2,16 \\
\cline { 2 - 3 } & Alt düzey yönetici & 2,22 \\
\cline { 2 - 3 } & Orta ve üst düzey yönetici & 2,10 \\
\hline \multirow{3}{*}{ Yıldırma Davranışları } & Ast & 1,69 \\
\cline { 2 - 3 } & Alt düzey yönetici & 2,22 \\
\cline { 2 - 3 } & Orta ve üst düzey yönetici & 1,82 \\
\hline
\end{tabular}

Tablo 16'dan da anlaşılacağı üzere banka çalışanların görev aldıkları pozisyona göre alt düzey yöneticilerin, psiko-sosyal etkiler boyutunda $(\bar{x}=2,54)$, fizyolojik etkiler boyutunda $(\bar{x}=2,59)$, işe yönelik etkiler boyutunda $(\bar{x}=2,22)$ ve son olarak yıldırma davranışları değişkeninde $(\bar{x}=2,22)$ en fazla ortalamaya sahip oldukları görülmektedir.

\section{TARTIŞMA VE SONUÇ}

Günümüzde çalışanlar yıldırma olaylarına ya da davranışlarına sık sık maruz kalmaktadır. $\mathrm{Bu}$ davranışlar, çalışanların sosyal yaşamı dışında psikolojik ve fizyolojik diğer birtakım sonuçlarla da karşı karşıya kalmasına neden olmaktadır. Bu sonuçlar kadar yıldırma davranışları çalışanların çalıştıkları örgütlerde iş verimliliğinin ve performansının düşmesi, moral ve motivasyon kaybı yaşaması, iş tatmininin azalması gibi örgütsel birçok sonuçları da doğurmaktadır. Sadece birey açısından değil aynı zamanda hem örgüt açısından hem de toplum açısından ilerleyen durumlar nedeniyle ciddi hasarlara yol açan yıldırma davranışları önemli bir problem haline gelmekte ve bu konuda çalışmalar yapmayı gerektirmektedir.

Bu çalışma son zamanlarda uluslararası ve ulusal çerçevede artan yıldırma olaylarına bağlı olarak yıldırma olgusuna dikkat çekmeyi ve yıldırma literatürünün zenginleştirilmesine katkı sağlamayı amaçlamaktadır. Bu amaç doğrultusunda yıldırma davranışlarının yaygın olduğu öngörülen bankacılık sektörü çalışanları araştırmanın örneklemi olarak belirlenmiştir. Örneklem olarak bankacılık sektörü çalışanlarının seçilmesinde bu sektörde yaşanan hızlı hizmet anlayışı ve artan değişim hızının getirdiği rekabetçi iş ortamının yıkıcı etkilerinin çalışanlar arasında yaşanan olumsuz davranışları artırdığı varsayımı bu sektörde araştırma isteğinin ortaya çıkışında etkili olmuştur.

Hizmet sektörünün yıldırma davranışlarının sık sık görüldüğü bir alan olması ve bu sektörlerde bireylerin çalışma ortamlarında sürekli olarak insanlarla yoğun iletişim halinde olması, stres yaratan performans baskılarıyla karşı karşıya kalmaları ve yine uzun çalışma saatlerinin söz konusu olması yıldırma davranışlarının görülme sıklığını bu ortamlarda daha fazla arttırmaktadır. Dolayısıyla bu noktada bu sektörde çalışanlar açısından hangi davranışların yıldırma olarak algılandığı ve yıldırma olaylarının ne seviyede yaşandığı konusunun incelenmesi önem taşımakta ve sonuçlar daha fazla değer kazanmaktadır.

Çalışmada nicel araştırma yöntemlerinden anket tekniği kullanılmıştır. Bu yöntemin kullanılmasının nedeni ise olgu ve olayların nesnelleştirilerek ölçülebilir hale getirilmesinin mümkün olmasıdır. Bu sayede elde edilen bulgular aracılığıyla konuya ilişkin sonuçların sayısal verilerle açıklanabilir olması sağlanmakta ve bazı durumlarda kıyaslama yapma özelliği tanımaktadır. Ancak ne yazık ki katılımcıların yaşadıkları yıldırma olay örgüsünü ve özellikle temel hassasiyetleri belirlemek bu yöntemlerde bütünüyle söz konusu olmamaktadır. Bu durum çalışmanın önemli bir kısıtını oluşturmaktadır. 
Denizli ilindeki 800 özel banka çalışanı ve 760 kamu bankası çalışanından \%10 kota örnekleme yöntemiyle 80 özel banka çalışanı ve 76 kamu bankası çalışanı olmak üzere toplamda 156 çalışana anket yöntemiyle ulaşılmıştır. Banka çalışanlarından elde edilen veriler ışı̆̆ında araştırmanın bulgularına ve hipotezlerine yönelik yapılan analizler ve ulaşılan sonuçlar aşağıdaki şekilde sıralanabilir:

Örnekleme ilişkin demografik detaylar özetlendiğinde, araştırmaya katılan banka çalışanlarının \%48,7'si kamu bankalarında ve \%51,3'ü de özel bankalarda çalışmaktadır. Ayrıca çalışanların \%54,5'lik çoğunlukla kadınlardan ve \%55,8'lik çoğunlukla evlilerden oluştuğu görülmektedir. Diğer taraftan katılımcıların yaşları incelendiğinde \%32,1 ile 31-35 yaş grupları arasındaki çalışanlardan ve \%15,4 ile 21-25 yaş grupları arasındaki çalışanlardan oluştuğu bilinmektedir. Eğitim düzeyi açısından ise \%67,9'unun lisans düzeyinde, $\% 16,7^{\prime}$ sinin lisansüstü düzeyinde ve son olarak \%15,4'nün ön lisans düzeyinde olduğu görülmektedir. Çalışanların iş hayatında elde ettikleri tecrübelere bakıldığında \%5,8'i 1 yıldan az, \%31,4'ü 1-5 yıl, \%32,7'si 6-10 yıl ve \%30,3'ü 10 yıldan fazla bir süredir iş hayatındadır. Bununla birlikte çalışanların \%17,3'ü 1 yıldan az, \%46,8'i 1-5 yıl, \%21,2'si 6-10 yıl ve \%14,7'si 10 yıldan fazla cevabını vererek mevcut işyerlerinde çalıştıklarını ifade etmişlerdir. Son olarak çalışanların pozisyonları ile ilgili yapılan analize göre \%53,8'i ast, $\% 26,9$ 'u alt düzey yönetici ve $\% 19,2$ 'si orta ve üst düzey yönetici pozisyonunda yer almaktadirlar.

Araştırma sonuçları incelendiğinde yıldırma davranışlarının alt boyutu olan "kendini gösterme ve iletişime saldırılar" boyutunda verilen yanıtların örneklem ortalamasına $(\bar{x}=1,7797)$ göre çalışanların düşük düzeyde yıldırmaya maruz kaldığı görülmektedir. Yıldırma davranışlarının ikinci boyutu olan "çalışma kalitesi ve mesleki duruma saldırılar" boyutunda gözlenen ortalamaya bakıldığında $(\bar{x}=2,0919)$ çalışanların bu boyut açısından düşük düzeyde yıldırma davranışlarının üçüncü boyutu olan "itibar ve saygınlığa saldırılar" boyutunda elde edilen veriler doğrultusunda hesaplanan ortalamaya $(\bar{x}=1,7870)$ göre bu boyut açısından çalışanların işyerinde düşük düzeyde yıldırma davranışları yaşadıkları sonucuna varılmaktadır. Yıldırma davranışlarının dördüncü ve son boyutu ile "sağlığa doğrudan saldırılar" boyutunda ortaya çıkan örneklem ortalaması $(\bar{x}=1,7179)$ çalışanların yine düşük düzeyde yıldırma davranışlarına maruz kaldıkları ifade edilebilir.

$\mathrm{Bu}$ çalışmada elde edilen sonuçlara bakıldığında çalışanların maruz kaldıkları yıldırma etkileri boyutlarından biri olan "psiko-sosyal etkiler" boyutunda hesaplanan ortalamaya $(\bar{x}=2,2620)$ göre, yıldırma etkilerinin ikinci boyutu olan "fizyolojik etkiler" boyutuna ilişkin ortaya çıkan ortalama $(\bar{x}=2,0888)$ incelendiğinde çalışanların karşı karşıya kaldıkları yıldırma davranışlarından dolayı düşük düzeyde, yıldırma etkilerinin üçüncü ve son boyutu olan "işe yönelik etkiler" boyutunda ise çalışanların vermiş oldukları yanıtların ortalamasına $(\bar{x}=2,3059)$ göre maruz kalınan yıldırma davranışlarının aynı şekilde belirtilerinin de düşük düzeyde yaşandiğı görülmektedir.

Araştırmanın bir diğer kısmında ise demografik değişkenler ile yıldırma etkilerinin boyutları arasında istatistiksel olarak farklılığın olup olmadığı incelenmiştir. Öncelikle çalışanların çalıştıkları bankaların sektörlerine yönelik iki değişkenli ifadelerde kullanılan istatistiksel olarak farklılıkların incelendiği Mann Whitney U testi uygulanmıştır. Bu testten elde edilen 
sonuçlara göre çalışanların çalıştıkları bankanın sektörünün yıldırma davranışları ile etkilerinin alt boyutları açısından bir farklılık oluşturmadığı görülmüştür.

Cinsiyetin değişkenlere göre farklılık oluşturup oluşturmadığının incelenmesi için yapılan analizde farklılığın olmadığı sonucuna ulaşılmıştır. Cinsiyet değişkeni ile ilgili olarak önceki çalışmalarda farklı sonuçlar elde edilmiştir. Literatürde bu konuda henüz bir fikir birliğinin olmadığ1 görülmektedir. Diğer taraftan medeni durum değişkeni ele alınarak analiz edilmiştir. Medeni durumun sadece psiko-sosyal etkiler boyutunda $(p=0,036)$ anlamlı bir farklılık oluşturduğu sonucuna varılmıştır. Buna göre araştırmada $\mathrm{H}_{1}$ hipotezi 0,05 anlamlılık düzeyinde desteklenmiştir. Yapılan analizler sonunda bu farklılığın bekâr çalışanlardan kaynaklandığ 1 ve bekâr çalışanların $(\bar{x}=2,41)$ evli çalışanlara $(\bar{x}=2,15)$ göre daha fazla psiko-sosyal etkilere maruz kaldıkları söylenebilir. Ancak medeni durum ile fizyolojik etkiler $(p=0,151)$, işe yönelik etkiler $(0,070)$ ve yıldırma davranışları $(p=0,256)$ arasında anlamlı bir farklılık bulunamamıştır.

Bu çalışmada yaş değişkeninin yıldırma ve etkilerinin boyutlarına göre farklılık oluşturup oluşturmadığının incelenebilmesi için ikiden çok değişkenli ifadelerin analizinde kullanılan Kruskal-Wallis Testi uygulanmıştır. Bu teste ilişkin elde edilen sonuçlara bakıldığında çalışanların maruz kaldıkları yıldırmanın fizyolojik etkileri yaşa göre farklılık

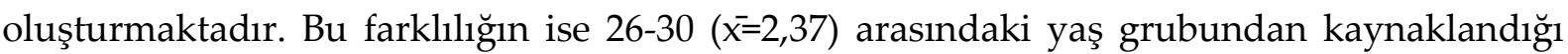
görülmektedir. Dolayısıyla araştırmada oluşturulan $\mathrm{H}_{2}$ hipotezi 0,05 anlamlılık düzeyinde desteklenmektedir. Diğer taraftan yaş değişkeni psiko-sosyal etkiler $(\mathrm{p}=0,119)$, işe yönelik etkiler $(p=0,088)$ ve yıldırma davranışları $(p=0,093)$ değişkenlerinde anlamlı bir farklılık oluşturmamaktadır.

Araştırmada elde edilen veriler doğrultusunda banka çalışanlarının eğitim durumları da Kruskal-Wallis Testi kullanılarak yıldırma ve etkilerinin boyutlarında farklılık oluşturup oluşturmadığı incelenmiştir. Yapılan analizler sonucunda değişkenlerin hepsinde de anlamlılık düzeyi 0,05 'ten büyük olarak hesaplanmıştır. Bu doğrultuda eğitim durumu ile psiko-sosyal etkiler $(p=0,052)$, fizyolojik etkiler $(p=0,130)$, işe yönelik etkiler $(p=0,115)$ ve yıldırma davranışları $(\mathrm{p}=0,119)$ arasında istatistiksel olarak anlamlı bir farklılık olmadığ sonucuna varılmıştır.

Bir diğer değişken olan iş hayatında geçirilen toplam sürenin, yıldırma ve etkilerinin boyutlarında Kruskal-Wallis testi sonuçlarına göre farklılığa yol açmadı̆̆ı sonucuna ulaşılmıştır. Her bir boyut incelendiğinde iş hayatında geçirilen süre ile psiko-sosyal etkiler $(\mathrm{p}=0,587)$, fizyolojik etkiler $(\mathrm{p}=0,474)$, işe yönelik etkiler $(\mathrm{p}=0,808)$ ve yıldırma davranışları $(\mathrm{p}=0,162)$ arasında anlamlı bir farklılığın olmadığı anlaşılmaktadır. Nitekim önceki çalışmalarda elde edilen sonuçlar bu çalışmada elde sonuçları desteklemektedir. Ayrıca Kruskal-Wallis Testinin uygulandığı çalışanların mevcut işyerindeki tecrübeleri ile yıldırma ve belirtilerinin boyutları arasında istatistiksel olarak bir farklılık olmadığı görülmektedir. Değişkenlere bakıldığında çalışanların işyerinde elde ettikleri tecrübe ile psiko-sosyal etkiler $(\mathrm{p}=0,729)$, fizyolojik etkiler $(\mathrm{p}=0,268)$, işe yönelik etkiler $(\mathrm{p}=0,522)$ ve yıldırma davranışları $(\mathrm{p}=0,344)$ arasında anlamlı bir farklılık bulunmamaktadır.

Son olarak araştırmada çalışanların görev aldıkları pozisyon ile ilgili olarak Kruskal-Wallis Testi yapılmıştır. Bu testin sonuçlarına göre pozisyon değişkeni ile psiko-sosyal etkiler $(p=0,015)$, fizyolojik etkiler $(p=0,000)$, işe yönelik etkiler $(p=0,035)$ ve yıldırma davranışları 
$(\mathrm{p}=0,000)$ arasında istatistiksel olarak anlamlı bir farklılığın olduğu sonucuna varılmıştır. Bu sonuçlar araştırma kapsamında oluşturulan $\mathrm{H}_{3}, \mathrm{H}_{4}, \mathrm{H}_{5}$ ve $\mathrm{H}_{6}$ hipotezlerini desteklemektedir. Ayrıca oluşan farklılığa ilişkin ortalamalara bakıldığında "psiko-sosyal etkiler" boyutunda $(\bar{x}=2,54)$, "fizyolojik etkiler" boyutunda $(\bar{x}=2,59)$, "işe yönelik etkiler" boyutunda $(\bar{x}=2,22)$ ve yıldırma davranışları değişkeninde $(\bar{x}=2,22)$ alt düzey çalışanların diğer pozisyondaki çalışanlardan farklılık gösterdiği anlaşılmaktadır.

Bu çalışmada elde edilen bulgular doğrultusunda aşağıdaki önerilere yer verilebilir:

- Bankaların yıldırma konusunda anket sonuçları düşük düzeyde çıkmasına karşılık yıldırma konusunda asıl amacın "sıfır yıldırma" olduğunu dikkate almalarının bu konuda önleyici adımların atılması için önemli görülmektedir. Özellikle çalışanların yıldırma olgusunda farkındalığının olması açısından bu konuda eğitilmesi ve bu yaklaşımla ileride meydana gelebilecek yıldırma davranışlarının önlenmesinde çalışanların kullanılabileceği yöntemler hakkında gerekli bilgilendirilmeleri önemli görülmektedir.

- Dikey anlamda ast ve üstler arasında yatay anlamda ise eşitler arasında ilişkilerin geliştirilmesi ve iletişimin zenginleştirilmesi önemlidir. Bu açıdan belirli aralıklarla çalışanların ve yöneticilerinin ortak katılım sağladığı sosyal etkinliklerin düzenlemesi ve yıldırma aktörlerine iletişim boşlukları yaratılarak fırsat tanınmamasına çalışılmalıdır. Böylece iletişimden kaynaklı özellikle yanlış anlama ve kişiyi tanımamaktan kaynaklı ortaya çıkabilecek yıldırma yapanları iştaha getiren çalışanları yalnızlaştırıcı, dışlayıcı ve soyutlayıcı davranışların engellenmesine yardımcı olunması örgüt kültürlerinin yıldırmaya karşı direnç oluşturmasında önemli görülmektedir.

- Gerek sosyal ağlar, vb. yollar ile gerekse afiş, broşür vb. yollar aracılığıyla bireylerin bir başkasına yıldırma davranışlarında bulunmasının insani suç olduğu ve yıldırma mağduru olmaları halinde de neler yapabileceklerinin duyurulmasının mağdurları sahiplenme anlamında hareket sağlamanın da önemli olduğu düşünülmektedir.

- Araştırma örnekleminde düşük düzeyde tespit edilse de çalışanlar için yıldırmanın ne olduğu, hangi davranışların yıldırma olarak tanımlandığı ve maruz kaldıkları yıldırma davranışlarına karşı nasıl mücadele edebileceklerine ilişkin bilgilendirme amaçlı özellikle yeni teknolojilerin kullanılması sağlanmalıdır. Bu konuda bankların gerekirse mobil uygulamalar geliştirmesi ve çalışanların erişim sağlayabilecekleri web siteleri oluşturması önerilebilir. Yine oluşturulan mobil uygulamalar ve web siteleri aracılığıyla bireylerin maruz kaldıkları yıldırma davranışlarını şikâyet edebilmelerinin sağlanması da takip açısından önemli olarak görülebilir.

- Finans sektöründe çalışanların iş sözleşmelerinde yıldırma uygulamayacaklarına yönelik maddelerin hazırlanması ve her çalışanın işe başlamadan önce etik kurallara uyacağının onayının alınması yönetsel destek sağlama bakımından önemli bir mesajdır. Bu çalışmanın devamını sağlayacak biçimde işyerlerinde çalışanların rahatlıkla görebileceği yerlere "Etik Çalışma İlkeleri” başlığı altında 
yıldırma vb. etik dışı davranışlara karşı bir kurumsal yaklaşım panosu oluşturulması yıldırma aktörlerine karşı caydırıcılık sağlama açısından etkili sonuçlar getirebilir.

\section{KAYNAKÇA}

Acar, A. B. ve Dündar, G. (2008), "İşyerinde Psikolojik Yıldırmaya (Mobbing) Maruz Kalma Sıklı̆̆ı İle Demografik Özellikler Arasındaki İlişkinin İncelenmesi", İstanbul Üniversitesi İşletme Fakültesi Dergisi, 37 (2), 111-120.

Aslım, G. ve Yaşar, A. (2016). “Gıda Tarım ve Hayvancılık Bakanlı̆̆ında Görev Yapan Veteriner Hekimlerde Mobbing (Yıldırma) Üzerine Bir Değerlendirme”, Erciyes Üniversitesi Veteriner Fakültesi Dergisi, 13 (1), 30-37.

Bayrak Kök, S. (2006). "İş Yaşamında Psiko-Şiddet Sarmalı Olarak Yıldırma Olgusu ve Nedenleri", Selçuk Üniversitesi Sosyal Bilimler Enstitüsü Dergisi, 16, 433-448.

Bayrak Kök, S., Mohan Bursalı, Y. ve Eroğlu, Ş. (2014). "Psikolojik Şiddetin Bireysel ve Örgütsel Yansıması: Yıldırma", Pamukkale Journal of Eurasian Socioeconomic Studies, 1(1), 4462.

Bilge, S. S. (2016). “Mobbing Terimi ve Türk Hukuk Düzeninde Incelenmesi”, Ankara Üniversitesi Hukuk Fakültesi Dergisi, 65 (4), 1245-1290.

Blase, J. and Blase, R. R. (2003). "Breaking the Silence: Overcoming the Problem of Principal Mistreatment of Teachers", Thousand Oaks, CA: Corwin Press.

Branch, S., Ramsay, S. and Barker, M. (2013). “Workplace Bullying, Mobbing and General Harassment: A Review", International Journal of Management Reviews, 15, 280-299.

Caponecchia, C. and Wyatt, A. (2009). "Distinguishing Between Workplace Bullying, Harassment and Violence: a Risk Management Approach", Journal of Occupational Health and Safety Australia and New Zealand, 25, 439-449.

Carneroa, M. A., Martinez, B. and Sanchez-Mangas, R. (2010). "Mobbing and its Determinants: The Case of Spain", Applied Economics, 42 (29), 3777-3787.

Cornoiu, T. S. and Gyorgy, M. (2013). "Mobbing in Organizations: Benefits of Identifying the Phenomenon", Procedia-Social and Behavioral Sciences, 78, 708-712.

Çimen, H. ve Saç, F. (2017). “Örgüt Başarısızlığının Nedenlerinden Biri: Mobbing", Karadeniz Uluslararası Bilimsel Dergi, 33 (33), 183-191.

Çoban, S. ve Nakip, M. (2007). "Yıldırma (Mobbing) Olgusunun İçsel Pazarlama İle İlişkisi: Nevşehir'de Bulunan Bankalar Örneği", Atatürk Üniversitesi İktisadi ve İdari Bilimler Dergisi, 21 (1), 307-320.

Çögenli, M. Z. ve Asunakutlu, T. (2016). "Akademide Mobbing: Adım Üniversiteleri Örneği", Erzincan Üniversitesi Sosyal Bilimler Enstitüsü Dergisi, 9 (1), 17-32.

Çögenli, M. Z. ve Karadaş, Y. (2019). “Belediye Çalışanlarının Karşılaştıkları Mobbing Davranışları: Akşehir Belediyesinde Ampirik Bir Çalışma", Uluslararası İktisadi ve İdari İncelemeler Dergisi, (Bor Özel Say1s1), 33-48. 
Dick, R. and Wagner, U. (2001). "Stress and Strain in Teaching: A Structural Equation Approach", British Journal of Educational Psychology, 71(2), 243-259.

Divincova, A. and Sivakova, B. (2014). Mobbing at Workplace and its Impact on Employee Performance", Human Resources Management and Ergonomics, 8 (2), 20-34.

Einarsen, S. (1999) "The Nature and Causes of Bullying at Work", International Journal of Manpower 20(1/2), 16-27.

Einarsen, S. (2000). "Harassment and Bullying at Work: A Review of Scandinavian Approach", Aggression and Violent Behavior, 5 (4), 379-401.

Ercan, İ. ve Kan, İ. (2004). “Ölçeklerde Güvenirlik ve Geçerlik”, Uludağ Üniversitesi Tıp Fakültesi Dergisi, 211-216.

Ertuna, D. G. ve Ertuna, E. (2015). "Yıldırma (Mobbing): Kuramsal Bir Çerçeve", Uluslararası Akademik Yönetim Bilimleri Dergisi, 1 (2), 127-138.

Ertürk, A. and Cemaloğlu, N. (204). "Causes of Mobbing Behavior", Procedia-Social and Behavioral Sciences, 116, 3669-3678.

Ferris, P. A. (2009). "The Role of the Consulting Psychologist in the Prevention, Detection, and Correction of Bullying and Mobbing in the Workplace", Consulting Psychology Journal: Practice and Research, 61(3), 169-189.

Genç, O. ve Erdiş, E. (2016). "İnşaat Sektöründe Mobbing Sorunsalı", Çukurova Üniversitesi Mühendislik-Mimarlık Fakültesi Dergisi, 30 (1), 215-222.

Giorgi, G., Ando, M., Arenas, A., Shoss, M. K. and Leon-Perez, J. M. (2013). “Exploring Personal and Organizational Determinants of Workplace Bullying and its Prevalence in a Japanese Sample" Psychology of Violence, 3 (2), 185-197.

Groeblinghoff, D. and Becker, M. (1996). "A Case of Mobbing and the Clinical Treatment of Mobbing Victims", European Journal of Work and Organizational Psychological, 5 (2), 277-294.

Gücenmez, S. (2007). "Psikolojik Şiddet ve Psikolojik Şiddetle Bir Mücadele Aracı Olarak Çalışan İlişkileri Yönetimi", Dokuz Eylül Üniversitesi Sosyal Bilimler Enstitüsü, Yüksek Lisans.

Hansen, A., Hogh, A., Garde, A. and Persson, R. (2014). “Workplace Bullying and Sleep Difficulties: A 2-Year Follow-Up Study", International Archives of Occupational and Environmental Health, 87, 285-294.

Hillard, J. R. (2009). "Workplace Mobbing: Are They Really out to Get Your Patient", Current Psychiatry, 8 (4), 45-51.

Hogh, A., Mikkelsen, E. G. and Hansen, A. M. (2011). "Individual Consequences of Workplace Bullying/Mobbing", in S. Einarsen, H. Hoel, D. Zapf and C. L. Cooper (Eds.), Bullying and Harassment in the Workplace: Developments in Theory, Research, and Practice (pp. 107-129), Boca Raton, FL: Taylor \& Francis.

İdiğ Çamuroğlu, M. ve Minibas Poussard, J. (2017). "Psikolojik Taciz: Türkiye Genelinde Bir Araştırma", Finans Politik ve Ekonomik Yorumlar, 54 (624), 53-68. 
Karabal, C., Sağbaş, M. ve Kaygın, E. (2016). "Mobbing İle Örgütsel Yabancılaşma Arasındaki İlişkiyi Belirlemeye Yönelik Bir Araştırma", Yüzüncü Yıl Üniversitesi İktisadi Ve İdari Bilimler Fakültesi Dergisi, (1), 140-162.

Karcığlu, F. ve Çelik, Ü. (2012). "Mobbing (Yıldırma) ve Örgütsel Bağhllı̆̆a Etkisi", Atatürk Üniversitesi İktisadi ve İdari Bilimler Dergisi, 26 (1), 59-75.

Karsavuran, S. (2014). "Sağglk Sektöründe Mobbing: Hastane Yöneticileri Üzerinde Bir Uygulama", Mustafa Kemal Üniversitesi Sosyal Bilimler Enstitüsü Dergisi, 11 (26), 271-296.

Karslığlu Yeni, G. "Mobbing İşyerinde Psikolojik Taciz", Ziraat Grup Matbaacılık Ankara, (webservice.turkmetal.org.tr/AsyaWebXmlService/file.do?id=46523, (Erişim tarihi: 03.09.2019)

Keashly, L., Trott, V. and MacLean, L. (1994). "Abusive Behavior in the Workplace: a Preliminary Investigation", Violence and Targets, 9 (4), 341-357.

Kehribar, A., Karabela, Ş. N., Yaşar, K. K., Okur, A., Derya, M., Özgür, C. ve Çankaya F. (2017). "Çalışma Hayatında Mobbing: Nedenleri, Bileşenleri ve Ülkemizdeki Hukuki Durumu”, Bakırköy Tıp Dergisi, 13, 1-9.

Keim, J. and McDermott, J. C. (2010). "Mobbing: Workplace Violence in the Academy", The Educational Forum, 74 (2), 167-173.

Kesebir, M. (2018). “Mobbing'in Çalışanların Performansı Üzerine Etkisi: İstanbul'da Bankacılık Sektörü Üzerine Bir Uygulama", Uşak Üniversitesi Sosyal Bilimler Dergisi, 11 (2), 154169.

Kızıldağ, B. (2019). “ Türk Liman Sahalarında Çalışan İşçilerdeki Örgütsel Stres, Mobbing ve Mesleki Tükenmişliğin İncelenmesi”, Bahçeşehir Üniversitesi Sosyal Bilimler Enstitüsü, Yüksek Lisans Tezi.

Koçak, Y. ve Yeşilyurt C. (2014). "Türk Hukuku Bakımından Mobbing”, Zeitschrift ür die Welt der Türken/Journal of World of Turks, 6 (1), 213-227.

Köse, S. ve Uysal, Ş. (2010). "Kamu Personelinin Yıldırma (Mobbing) ve Boyutları Hakkındaki Düşünceleri Üzerine Bir Çalışma: Manisa Tarım İl Müdürlüğ̈̈ Örneğgi", Celal Bayar Üniversitesi Sosyal Bilimler Dergisi, 8 (1), 261-276.

Leymann, H. (1996). "The Content and Development of Mobbing at Work" European Journal of Work and Organizational Psychology, 5(2), 165-184.

Mercanlığlu, Ç. (2010). “Çalışma Hayatında Psikolojik Tacizin (Mobbing) Nedenleri, Sonuçları ve Türkiye'deki Hukuksal Gelişimi", Organizasyon ve Yönetim Bilimleri Dergisi, 2 (2), 3746.

Mizrahi, R. (2013). "Çalışma Hayatında Mobbing İle Mücadele Yöntemleri", Sosyal ve Beşeri Bilimler Dergisi, 5 (2), 443-452.

Mobbing İle Mücadele Derneği (2017). "Mobbing ile İlgili Mevzuat", https://www.mobbing.org.tr/mobbing-ile-ilgili-hukuki-mevzuat (12.10.2021 tarihinde erişildi.) 
Mulder, R., Bos, A. E. R., Pouwelse, M. and van Dam, K. (2017). "Workplace Mobbing: How the Victim's Coping Behavior Influences Bystander Responses", The Journal of Social Psychology, 157 (1), 16-29.

Niedl, K. (1996). "Mobbing and Well-Being: Economic and Personnel Development Implications", European Journal of Work and Organizational Psychology, 5 (2), 239249.

Özdemir, E., Ünsar, A. S. ve Oğuzhan, A. (2012). “İşyerinde Psikolojik Yıldırmanın İş Tatminine Etkisi: Bankacılık Sektöründe Bir Uygulama", Yalova Sosyal Bilimler Dergisi, 2 (3), 129148.

Özyer, K. ve Orhan, U. (2012). “Akademisyenlere Uygulanan Psikolojik Tacize Yönelik Ampirik Bir Araştırma", Ege Akademik Bakış, 12 (4), 511-518.

Palaz, S. (2016). "Psikolojik Taciz ve Yıldırma Davranışları Üzerine Bir Araştırma: Banka Çalışanları Örne ği", Karatahta İş Yazıları Dergisi, 5, 19-36.

Palaz, S., Özkan, S., Sarı, N., Göze, F., Şahin, N. ve Akkurt, Ö. (2008). "İş Yerinde Psikolojik Taciz (Mobbing) Davranışlarn Üzerine Bir Araştırma; Bandırma Örneği", "İş, Güç" Endüstri İlişkileri ve İnsan Kaynakları Dergisi, 10 (4), 41-58.

Pehlivan, M. (2015). “Bireysel Ayrılıklar ve Toplumsal Dezavantajlar Çerçevesinde İşyerinde Psikolojik Taciz: Mobbing", MAKÜ İktisadi ve İdari Bilimler Fakültesi Dergisi, 2 (2), 6578.

Polat, O. ve Pakiş, I. (2012). "Mobbing: İşyerinde Psikolojik Taciz", Acıbadem Üniversitesi Sağlık Bilimleri Dergisi, 3 (4), 211-217.

Raknes, I., Pallesen, S., Mageroy, N., Moen, B. E., Bjorvatn, B. and Einarsen, S. (2014). "Exposure to Bullying Behaviors as a Predictor of Mental Health Problems Among Norwegian Nurses: Results from the Prospective SUSSH-Survey", International Journal of Nursing Studies, 51, 479-487.

Rayner, C. (1997). "The Incidence of Workplace Bullying", Journal of Community and Applied Social Psychology, 7, 199-208.

Rayner, C. and Hoel, H. A. (1997). "A Summary Review of Literature Relating to Workplace Bullying", Journal of Community and Applied Social Psychology, 7, 181-191.

Safina, D. and Podgornaya, A. (2014). "Mobbing as an Organizational Phenomenon Impeding Implementation of Changes", Mediterranean Journal of Social Sciences, 5 (18), 187-192.

Sloan, L., Matyok, T., Schmitz, C. L. and Short, G. (2010). "A Story to Tell: The Cost of Bullying and Mobbing in the Workplace", International Journal of Business and Social Science, 1 (3), 87-97.

Sperry, L. (2009). "Mobbing and Bullying: The Influence of Individual, Work Group, and Organizational Dynamics on Abusive Workplace Behavior", Consulting Psychology Journal: Practice and Research, 61 (3), 190-201.

Staub, S. (2015). "Mobbing in Academia: Case Analysis", International Journal of School and Cognitive Psychology, 2 (1), 1-7. 
Şen, N. (2017). "İş Hayatında Psikolojik Şiddet (Mobbing): Trabzon Örneği", İmgelem, 1 (1), 135151.

Şerifoğlu, E. (2019). "Mobbingin Özel Sektör Çalışanları Üzerindeki Etkileri: Bir Nitel Araştırma" Yıldız Teknik Üniversitesi Sosyal Bilimler Enstitüsü, Yüksek Lisans Tezi.

Tetik, S. (2010). "Mobbing Kavramı: Birey ve Örgütler Açısından Önemi", Karamanoğlu Mehmetbey Üniversitesi Sosyal ve Ekonomik Araştırmalar Dergisi, 12 (18), 81-89.

Tinaz, P. (2006a). "İş Yerinde Psikolojik Taciz (Mobbing)", Çalışma ve Toplum Dergisi, 4, 13-28.

Tınaz, P. (2006b). “Mobbing: İşyerinde Psikolojik Taciz", Çalışma ve Toplum, 3, 11-22.

Trepanier, S. G., Fernet, C. and Austin, S. (2015). A Longitudinal Investigation of Workplace Bullying, Basic Need Satisfaction and Employee Functioning", Journal of Occupational Health Psychology, 20 (1), 105-116.

Tunç, Y. E. (2017). "Türk İş Hukukunda Mobbing”, Global Business Research Congress (GBRC2017), 3, 409-422.

Türkiye Büyük Millet Meclisi Kadın Erkek Fırsat Eşitliği Komisyonu (2011). "İşyerinde Psikolojik Taciz (Mobbing) ve Çözüm Önerileri Komisyon Raporu”, (Rapor No:6), TBMM Basımevi, Ankara.

Üngüren, E. (2008). "Örgütsel Çatışma Yönetimi Üzerine Konaklama İşletmelerinde Bir Araştırma", Uluslararası Sosyal Araştırmalar Dergisi, 1 (5), 880-909.

Wachs, J. (2009). "Workplace Incivility, Bullying, and Mobbing”, AAOHN Journal, 57 (2), 88-88.

Wornham, David (2003). "A Descriptive Investigation of Morality and Victimisation at Work", Journal of Business Ethics, 45, 29-40.

Vartia, M. (1996) “The Sources of Bullying: Psychological Work Environment and Organizational Climate", European Journal of Work and Organizational Psychology, 52, 203-214.

Zapf, D., Knortz, C. and Kulla, M. (1996). "On the Relationship Between Mobbing Factors and Job Content, Social Work Environment and Health Outcomes", European Journal of Work and Organizational Psychology, 5 (2), 215-237.

Zapf, D. and Leymann, H. (1996). "Mobbing and Victimization at Work", European Journal of Work and Organizational Psychology, 5 (2), 209-222. 